\title{
Hexavalent Chromium Removal via Photoreduction by Sunlight on Titanium-Dioxide Nanotubes Formed by Anodization with a Fluorinated Glycerol-Water Electrolyte
}

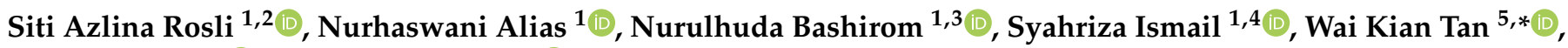 \\ Go Kawamura ${ }^{6}\left(\mathbb{D}\right.$, Atsunori Matsuda ${ }^{6}\left(\mathbb{D}\right.$ and Zainovia Lockman ${ }^{1, *}$
}

1 Green Electronic Nanomaterials Group, School of Materials and Mineral Resources Engineering, Engineering Campus, Universiti Sains Malaysia, Nibong Tebal 14300, Penang, Malaysia; ct.azlinar@gmail.com (S.A.R.); haswani.alias@gmail.com (N.A.); hudabashirom@unimap.edu.my (N.B.); syahriza@utem.edu.my (S.I.)

2 Faculty of Applied Sciences, Universiti Teknologi MARA Cawangan Pulau Pinang, Permatang Pauh Campus, Permatang Pauh 13500, Penang, Malaysia

3 Faculty of Chemical Engineering Technology, Kompleks Pusat Pengajian Jejawi 2, Universiti Malaysia Perlis, Taman Muhibbah, Jejawi 02600, Arau, Perlis, Malaysia

4 Carbon Research Technology Group, Faculty of Manufacturing Engineering, Universiti Teknikal Malaysia Melaka, Durian Tunggal 76100, Malacca, Malaysia

5 Institute of Liberal Arts and Sciences, Toyohashi University of Technology, Toyohashi 441-8580, Aichi, Japan

check for

updates

Citation: Rosli, S.A.; Alias, N.;

Bashirom, N.; Ismail, S.; Tan, W.K.;

Kawamura, G.; Matsuda, A.;

Lockman, Z. Hexavalent Chromium Removal via Photoreduction by Sunlight on Titanium-Dioxide Nanotubes Formed by Anodization with a Fluorinated Glycerol-Water Electrolyte. Catalysts 2021, 11, 376. https://doi.org/10.3390/ catal11030376

Academic Editors: Leire Ruiz-Rubio, Hideyuki Katsumata, Jose Luis Vilas Vilela and Huiyao Wang

Received: 14 February 2021

Accepted: 10 March 2021

Published: 13 March 2021

Publisher's Note: MDPI stays neutra with regard to jurisdictional claims in published maps and institutional affiliations.

Copyright: (c) 2021 by the authors. Licensee MDPI, Basel, Switzerland. This article is an open access article distributed under the terms and conditions of the Creative Commons Attribution (CC BY) license (https:// creativecommons.org/licenses/by/ $4.0 /)$
6 Department of Electrical and Electronic Information Engineering, Toyohashi University of Technology, Toyohashi 441-8580, Aichi, Japan; gokawamura@ee.tut.ac.jp (G.K.); matsuda@ee.tut.ac.jp (A.M.)

* Correspondence: tan@las.tut.ac.jp (W.K.T.); zainovia@usm.my (Z.L.); Tel.: +81-532-44-6808 (W.K.T.); +60-4-599-6178 (Z.L.)

Abstract: In this paper, titanium-dioxide $\left(\mathrm{TiO}_{2}\right)$ nanotubes (TNTs) are formed by anodic oxidation with a fluorinated glycerol-water (85\% and $15 \%$, respectively) electrolyte to examine the effect of fluoride ion concentration, time, and applied voltage on TNT morphologies and dimensions. For fluoride ion concentration, the surface etching increases when the amount of ammonium fluoride added to the electrolyte solution increases, forming nanotube arrays with a clear pore structure. At a constant voltage of $20 \mathrm{~V}$, TNTs with an average length of $\sim 2 \mu \mathrm{m}$ are obtained after anodization for $180 \mathrm{~min}$. A prolonged anodization time only results in a marginal length increment. The TNT diameter is voltage dependent and increases from approximately $30 \mathrm{~nm}$ at $10 \mathrm{~V}$ to $310 \mathrm{~nm}$ at $60 \mathrm{~V}$. At $80 \mathrm{~V}$, the structure is destroyed. TNTs formed at $20 \mathrm{~V}$ for $180 \mathrm{~min}$ are annealed to induce the $\mathrm{TiO}_{2}$ anatase phase in either air or nitrogen. When ethylenediaminetetraacetic acid is added as a hole scavenger, $100 \%$ hexavalent chromium removal is obtained after $120 \mathrm{~min}$ of sunlight exposure for nitrogen-annealed TNTs.

Keywords: $\mathrm{TiO}_{2}$; anodization; nanotubes; glycerol; $\mathrm{Cr}(\mathrm{VI})$ reduction; photocatalysis; nitrogen

\section{Introduction}

In recent years, the application of $\mathrm{TiO}_{2}$ as a photocatalyst to reduce heavy metals such as hexavalent chromium $[\mathrm{Cr}(\mathrm{VI})]$ has gained academic attention. $\mathrm{Cr}(\mathrm{VI})$ is used in several industrial processes, including chrome plating, stainless steel manufacturing, chrome pigment formation, and leather tanning. Among these, chrome plating is responsible for producing large amounts of wastewater containing $\mathrm{Cr}(\mathrm{VI})$ ions. Fortunately, $\mathrm{Cr}(\mathrm{VI}) \mathrm{com}$ pounds can be eliminated from industrial wastewater by chemical precipitation, flotation, adsorption, ion exchange, and electrochemical deposition [1].

The reduction of $\mathrm{Cr}(\mathrm{VI})$ to chromium [Cr(III)] is also conducted to treat $\mathrm{Cr}(\mathrm{VI})$-laden wastewater by photocatalysis [2]. This process is beneficial because, whereas $\mathrm{Cr}(\mathrm{VI})$ is mobile, corrosive, and toxic to humans, $\mathrm{Cr}$ (III) is non-toxic and an essential dietary element. Industrial activities such as metal finishing and chrome plating produce wastewater with large amounts of $\mathrm{Cr}(\mathrm{VI})$, which can contaminate water bodies and soil. The uptake of $\mathrm{Cr}(\mathrm{VI})$ 
in plants from $\mathrm{Cr}(\mathrm{VI})$-contaminated soil was reviewed by Shahid et al. in 2017 [3], and the existence of $\mathrm{Cr}(\mathrm{VI})$ in rice was reported by Rudzi et al. in 2018 [4]. Preventing $\mathrm{Cr}(\mathrm{VI})$ from contaminating the environment can be achieved by properly removing the ions from their discharge point. As mentioned, $\mathrm{Cr}$ (VI) can be reduced to $\mathrm{Cr}(\mathrm{III})$ by photocatalysis process. This process requires a photocatalyst, such as titanium dioxide $\left(\mathrm{TiO}_{2}\right)$, which is very effective due to the negative position of the conduction-band electrons that can reduce $\mathrm{Cr}(\mathrm{VI})$ to $\mathrm{Cr}(\mathrm{III})$.

$\mathrm{TiO}_{2}$ nanotubes (TNTs) can be synthesized by template-assisted deposition $[5,6]$, hydrothermal treatment $[7,8]$, atomic layer deposition $[3,9]$, sol-gel treatment $[10,11]$, and titanium (Ti) anodization [12-22]. Of these methods, anodization is preferred because of its feasibility, cost-effectiveness, and robustness. More importantly, anodization also enables the formation of self-aligned TNT arrays [23]. In the anodization process, the electrolyte is an essential parameter with respect to controlling the morphological features of the anodic film. For nanotubular formation, a presence of fluoride ions has been identified as the most important parameter.

Zwilling and co-workers [13] fabricated highly ordered porous anodic $\mathrm{TiO}_{2}$ films in chromic acid containing hydrofluoric acid. This so-called first-generation electrolyte resulted in short TNTs $(\sim 500 \mathrm{~nm})$ due to excessive etching. This was followed by the development of a second-generation electrolyte, i.e., a buffered solution containing sodium fluoride or ammonium fluoride $\left(\mathrm{NH}_{4} \mathrm{~F}\right)$, which produces TNTs longer than $5 \mu \mathrm{m}$ [24]. Even longer TNTs $(>10 \mu \mathrm{m})$ have been formed using third-generation organic fluoride electrolytes, such as ethylene glycol, glycerol, and formamide. However, organic electrolytes require oxygen species for stable oxide growth [25-31]; water is commonly added as the oxygen provider. Recent research has reported the use of alkaline species for electrolytes to obtain even longer TNT formation, such as potassium hydroxide, lithium hydroxide, and sodium hydroxide [32-38]. The use of hydrogen peroxide has also been explored, and TNTs with a grassy surface structure have been reported [39].

In this work, TNTs are produced by Ti anodization in glycerol-water electrolyte. Anodic film grew in glycerol-water electrolyte was examined, including the success of self-aligned TNTs formation, by varying $\mathrm{NH}_{4} \mathrm{~F}$ content, time, and anodization voltage. To the best of our knowledge, research on TNTs formation with the electrolyte in question is lacking, especially with respect to using photocatalysts for $\mathrm{Cr}(\mathrm{VI})$ reduction in synthetic wastewater. In fact, there is a complete lack of work reporting on the use of highly serrated TNTs for $\mathrm{Cr}(\mathrm{VI})$ reduction under sunlight. The formation TNTs with serrated walls, could increase the surface area for more catalytic sites that can enhance reactions. Long TNTs with a clear surface opening are also preferred for the catalytic process to take advantage of both the interior and the exterior of the nanotubes.

$\mathrm{TiO}_{2}$ is a wide-bandgap semiconductor, and, therefore, electron-hole pair generation is only possible under ultraviolet (UV) radiation. However, sunlight activation can be achieved by the mid-gap states induced by the defects created when TNTs are heat-treated in a reduced atmosphere or in a nitrogen-containing environment. In this paper, the formed TNTs are annealed in nitrogen, and their ability to reduce $\mathrm{Cr}(\mathrm{VI})$ via photoreduction to $\mathrm{Cr}(\mathrm{III})$ is reported. Moreover, to ensure an effective reduction process, ethylenediaminetetraacetic acid (EDTA) was used as a hole scavenger. This is necessary, as a hole scavenger can suppress the recombination of electron-hole pairs, hence the increased in the number of free electrons available for $\mathrm{Cr}(\mathrm{VI})$ reduction.

\section{Results and Discussion}

2.1. Anodic Oxide Features on Titanium Anodized in Water-Glycerol Electrolyte

2.1.1. Effect of $\mathrm{NH}_{4} \mathrm{~F}$ Concentration

Figure 1 shows the cross-section FESEM morphologies of anodized Ti in the waterglycerol electrolyte with various amounts of $\mathrm{NH}_{4} \mathrm{~F}$; insets are the surface images of the corresponding samples. Anodization was conducted at $20 \mathrm{~V}$ for $90 \mathrm{~min}$. From the micrographs, it is evident that the amount of $\mathrm{NH}_{4} \mathrm{~F}$ added to the electrolyte influences the length 
and diameter of the TNTs. Figure 2 summarizes the findings, from which it is evident that, apart from the $0.1 \mathrm{wt} . \% \mathrm{NH}_{4} \mathrm{~F}$ sample, a nanotubular structure was successfully formed with the length and diameter affected by the amount of fluoride ions. The TNT length increased from 1.6 to $2.0 \mu \mathrm{m}$ when anodized with the electrolyte containing 0.3 and $0.5 \mathrm{wt} . \%$ $\mathrm{NH}_{4} \mathrm{~F}$, respectively. However, higher concentrations of $\mathrm{NH}_{4} \mathrm{~F}(>0.7 \mathrm{wt} . \%)$ reduced the length, which can be attributed to severe chemical dissolution at the TNTs surface due to the increased number of fluoride ions. Moreover, the TNT diameter increased, albeit marginally, with an increase in $\mathrm{NH}_{4} \mathrm{~F}$ content.

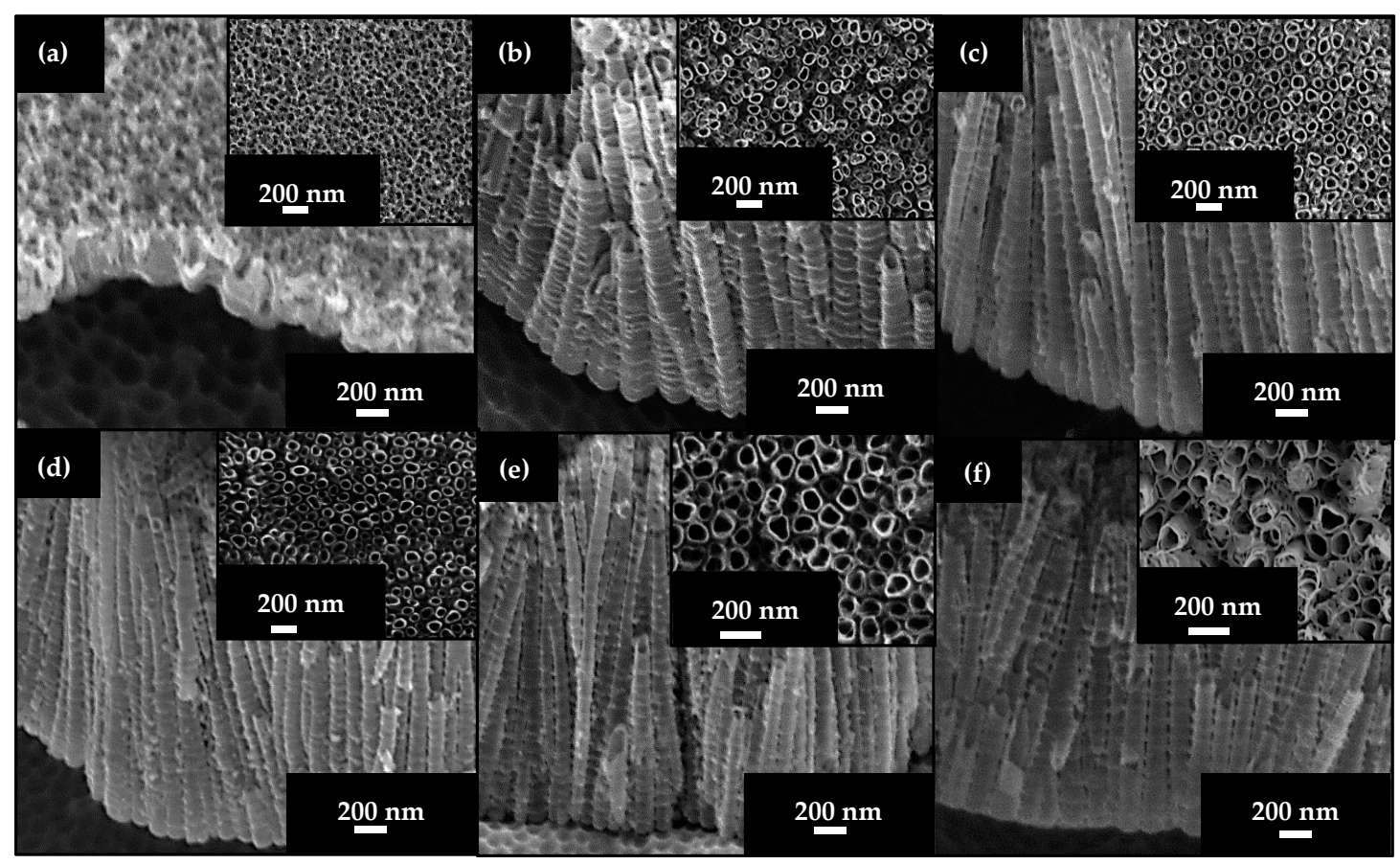

Figure 1. FESEM of anodized $\mathrm{TiO}_{2}$ at $20 \mathrm{~V}$ for $90 \mathrm{~min}$ in the glycerol-water electrolyte with different $\mathrm{NH}_{4} \mathrm{~F}$ concentrations: (a) 0.1, (b) 0.3 , (c) 0.5 , (d) 0.7 , (e) 0.9 , and (f) $1.0 \mathrm{wt} . \%$.

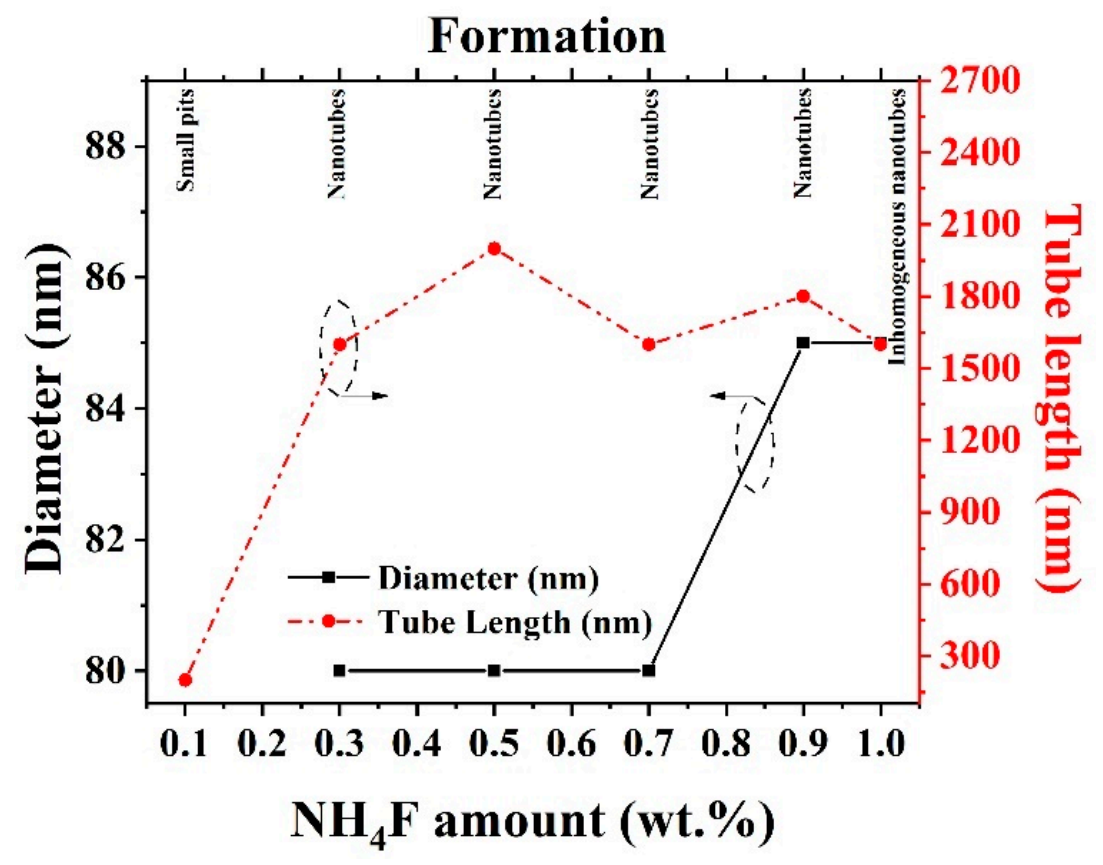

Figure 2. Anodic $\mathrm{TiO}_{2}$ formed at $20 \mathrm{~V}$ for $90 \mathrm{~min}$ in the glycerol-water electrolyte with different $\mathrm{NH}_{4} \mathrm{~F}$ concentrations: $0.1,0.3,0.5,0.7,0.9$, and $1.0 \mathrm{wt}$. $\%$. 
The formation of $\mathrm{TiO}_{2}$ by anodic oxidation is described by Equation (1). At the initial stage of the anodization process, a barrier layer comprising defective $\mathrm{TiO}_{2}$ was formed. Pores then developed because of the chemical dissolution of the barrier layer (Equation (2)) and for discrete nanotubes formation, the pores must be separated.

$$
\begin{gathered}
\mathrm{Ti}^{4+}+2 \mathrm{H}_{2} \mathrm{O} \rightarrow \mathrm{TiO}_{2}+4 \mathrm{H}^{+}+4 e^{-} \\
\mathrm{TiO}_{2}+6 \mathrm{~F}^{-}+4 \mathrm{H}^{+} \rightarrow\left[\mathrm{TiF}_{6}\right]^{2-}+2 \mathrm{H}_{2} \mathrm{O}
\end{gathered}
$$

During the anodization process, ion migration across the anodic film is essential to increase the oxide thickness. The migration of fluoride ions is believed to be faster than any other inward-migrating ions, and, thus, a fluoride-rich layer (FRL) will form at the oxide-Ti interface [40]. The bottom part of the nanotubes, as seen in the cross-sectional images, is scallop-shaped, indicating a flow mechanism in the oxide pore formation. According to this mechanism, FRL will eventually be displaced as inter pore materials. Pores are separated when the FRL is dissolved by water, resulting in discrete nanotubes. At larger amounts of $\mathrm{NH}_{4} \mathrm{~F}$, a thicker FRL is thought to form around the pores, and, as the electrolyte is excess with water, the dissolution of this FRL will result in TNTs with very thin walls. As seen from the FESEM images, the sample prepared in the electrolyte with $1.0 \mathrm{wt} . \% \mathrm{NH}_{4} \mathrm{~F}$ had walls thinner than $10 \mathrm{~nm}$, and the severe dissolution resulted in an inhomogeneous surface structure. From here, $0.5 \mathrm{wt}$.\% $\mathrm{NH}_{4} \mathrm{~F}$ was chosen as the optimum amount of fluoride ion in the electrolyte, as it is adequate for surface etching, and the nanotubes formed also had considerable length, as shown in Figure 2.

\subsubsection{Effect of Anodization Voltage}

Apart from $\mathrm{NH}_{4} \mathrm{~F}$ content, anodization voltage is also known to play an essential role in tuning TNT dimensions [20]: a higher anodization voltage results in a higher oxidation rate, resulting in the formation of more $\mathrm{H}^{+}$ions in the electrolyte (Equation (1)). If the number of $\mathrm{H}^{+}$ions in the electrolyte increases, chemical dissolution increases, resulting in larger and longer TNTs. Nevertheless, there is a limit to the voltage applied, as a high voltage may induce an overly rapid electric field dissolution, destroying the nanotubular structure. As reported by Lockman et al., depending on the electrolyte used, there is a threshold voltage at which the TNT structure is formed; TNTs are formed above the threshold voltage, while a lower voltage would result in insufficient electric field dissolution, generating compact anodic film or film with small pores [20]. Figure 3 shows the FESEM morphologies, whereas Figure 4 summarizes the anodic film features as a function of applied voltage. Ti anodized at $1 \mathrm{~V}$ has a rather compact surface oxide without any noticeable microstructure, as shown by Figure 3a. Small pits with 5-8 nm diameters can be observed in Figure $3 \mathrm{~b}$ for the sample anodized at $3 \mathrm{~V}$. Increasing the anodization voltage to $5 \mathrm{~V}$ results in larger pits (diameter $\sim 10 \mathrm{~nm}$ ) with an increased distribution, as shown in Figure 3c.

The corresponding cross-sectional FESEM image shows that the thickness of the anodic layer is approximately $80 \mathrm{~nm}$. TNTs formed on the foil with an average diameter of $30 \mathrm{~nm}$ (Figure 3d) for the $10 \mathrm{~V}$ sample and $50 \mathrm{~nm}$ (Figure 3e) for the $15 \mathrm{~V}$ sample. The length of the nanotubes ranged from approximately 200 to $500 \mathrm{~nm}$. The $20 \mathrm{~V}$ anodized sample resulted in TNTs with a length of $\sim 1.5 \mu \mathrm{m}$ and an outer diameter of $80 \mathrm{~nm}$ (Figure 3f).

As the anodization voltage was increased to $30 \mathrm{~V}$, the diameter increased to $150 \mathrm{~nm}$ (Figure 3g); at $40 \mathrm{~V}$, it increased to $250 \mathrm{~nm}$ (Figure 3h); however, the nanotubes length for both samples did not differ by much $(\sim 2.5 \mu \mathrm{m})$. Anodization at $60 \mathrm{~V}$ resulted in TNTs with a diameter and length of $310 \mathrm{~nm}$ and $2.6 \mu \mathrm{m}$, respectively (Figure 3i); for this electrolyte, it appears that voltage affects TNT diameter but not length. At $80 \mathrm{~V}$, the nanotubular structure was destroyed (Figure 3j) due to the overaccelerated electric field dissolution causing severe polarization and weakening of the Ti-O bond, which led to the formation of an irregular porous oxide structure. Figure $3 \mathrm{k}$ shows the TEM image of the $20 \mathrm{~V}$ sample taken from the bottom part of the TNTs, demonstrating TNTs with scallop-shaped barrier layer of $\sim 20 \mathrm{~nm}$ 
thickness. If compared with anodic TNTs formed in ethylene glycol [32-38], the thickness of the barrier layer for the abovementioned sample is rather large, perhaps because of the excess water in the glycerol, which increases oxidation. In Figure 31, a single nanotube is shown with serrated walls.

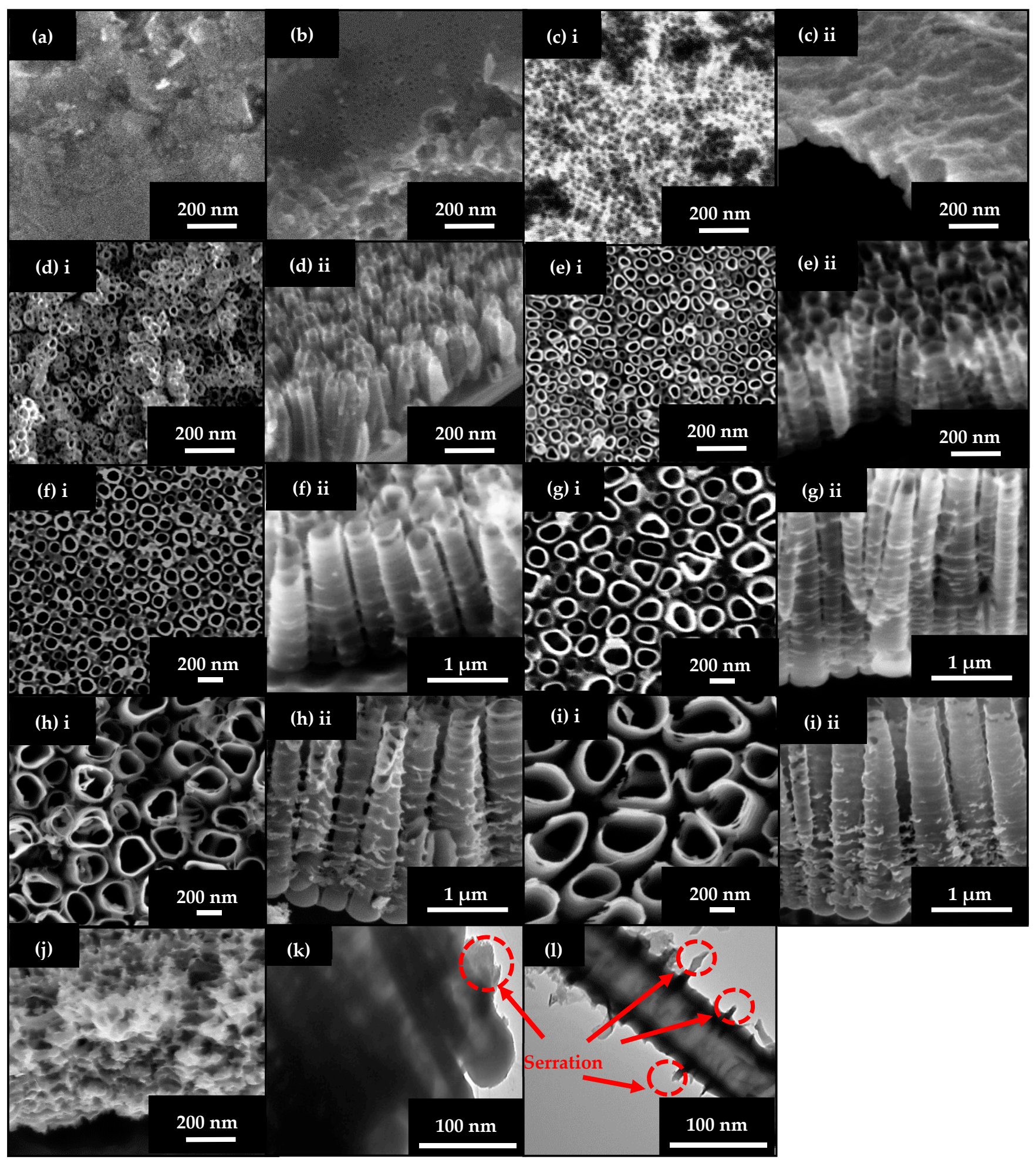

Figure 3. FESEM images of anodized TiO2 at different voltages: (a) 1, (b) 3, (c) 5, (d) 10, (e) 15, (f) 20, (g) 30, (h) 40, (i) 60, and (j) 80 V. Surface morphology views: Figure (c) i, (d) i, (e) i, (f) i, (g) i, (h) i and (i) i and cross-sectional views: Figure (c) ii, (d) ii, (e) ii, (f) ii, (g) ii, (h) ii and (i) ii. TEM images for the $20 \mathrm{~V}$ sample (k) bottom, and (1) to show serrated walls. All anodization was performed in glycerol-water electrolyte added to it $0.5 \mathrm{wt}$ \% $\mathrm{NH}_{4} \mathrm{~F}$ electrolyte for $90 \mathrm{~min}$. 


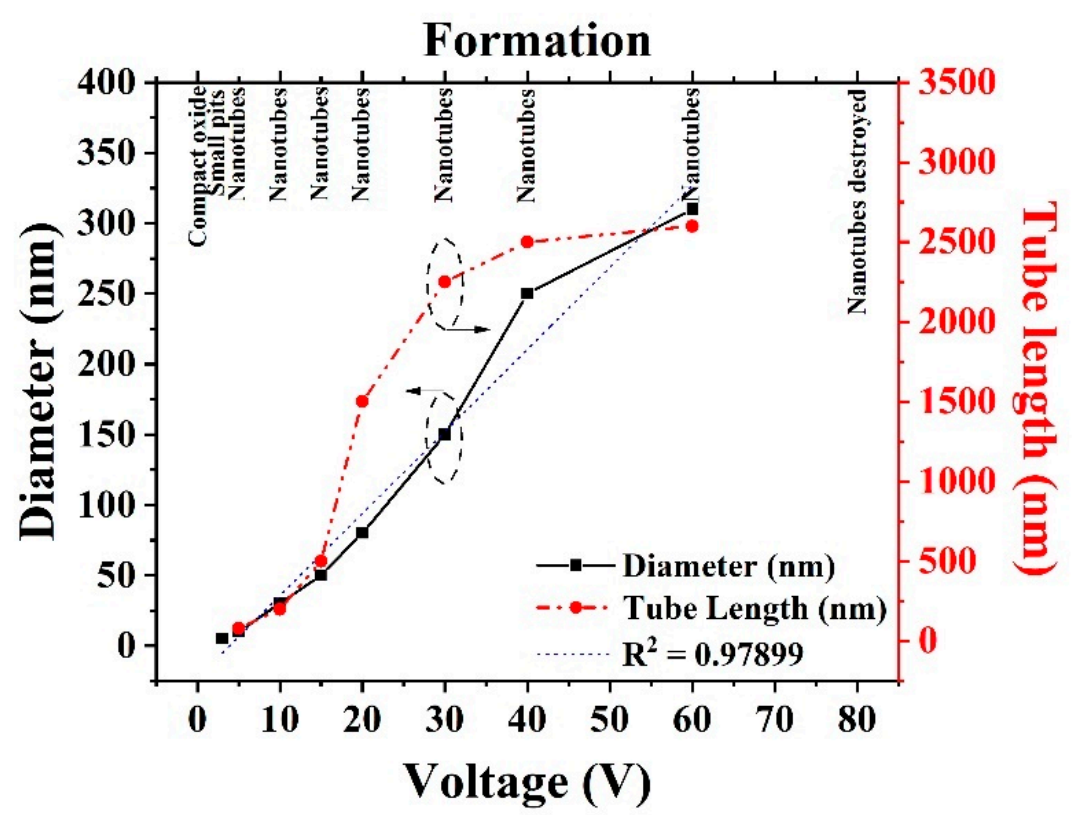

Figure 4. Anodic film formation features $\left(\mathrm{NH}_{4} \mathrm{~F}=0.5 \mathrm{wt} . \%\right.$, time $\left.=90 \mathrm{~min}\right)$ at 1, 3, 5, 10, 15, 20, 30, 40, 60 , and $80 \mathrm{~V}$ in a water-glycerol electrolyte.

\subsubsection{Effect of Variation Reaction Time}

Foils were then anodized at $20 \mathrm{~V}$ but at varying times from 1 to $720 \mathrm{~min} ; 20 \mathrm{~V}$ was selected, as it produced TNTs with a diameter smaller than $100 \mathrm{~nm}$. A time variation experiment was performed to investigate the influence of anodization duration over TNT dimensions. The FESEM images in Figure 5 show the morphologies of the anodic film, and Figure 6 summarizes the anodic film features formed at different anodization times. As seen in Figure 5a, anodization for 1 min resulted in anodic films with a thickness of $\sim 10 \mathrm{~nm}$ and randomly distributed pits on the surface. The pit diameter increased to $\sim 50 \mathrm{~nm}$ after anodization for $15 \mathrm{~min}$ (Figure $5 \mathrm{~b}$ ). From the cross-sectional morphology, it is evident that a self-aligned nanotubular structure formed beneath this pitted region, indicating inadequate surface etching. A more obvious nanotube structure was obtained for the sample anodized for $30 \mathrm{~min}$ (Figure 5c). The TNT opening was also very clear, suggesting that surface etching is time dependent. Moreover, TNTs length was longer for this sample than for the 15 min sample.

The length increased further with an increase in anodization time; at $60 \mathrm{~min}$, the TNT length increased to $700 \mathrm{~nm}$; at $90 \mathrm{~min}$, it increased to $1.5 \mu \mathrm{m}$; and, at $120 \mathrm{~min}$, it increased to $1.8 \mu \mathrm{m}$, as shown in Figure $5 \mathrm{~d}-\mathrm{f}$, respectively. However, the length remained constant at $\sim 2 \mu \mathrm{m}$ for samples anodized for 180-720 min (Figure 5g-i). The TNT diameter was $\sim 80 \mathrm{~nm}$ for all samples, indicating that the diameter is independent of anodization time. Similar findings have been reported [18].

\subsubsection{Effect of Annealing Environment.}

Samples prepared by anodization at $20 \mathrm{~V}$ were annealed either in air or nitrogen at $450{ }^{\circ} \mathrm{C}$ for $3 \mathrm{~h}$. The XRD pattern in Figure $7 \mathrm{a}$ shows that the as-anodized TNTs are amorphous, and, after annealing, anatase $\mathrm{TiO}_{2}$ (ICSD: 98-010-7874) can be identified from peaks at $25.4^{\circ}, 48.1^{\circ}$, and $54.7^{\circ}$, corresponding to the (011), (020), and (121) planes, respectively. Minimal differences can be observed for samples annealed in air and nitrogen, apart from a slight shift in the (011) peak, as shown in Figure 7b. This shift is attributed to lattice distortion [41], perhaps induce by the substitution of nitrogen within the crystal lattice, which results in strain [42-44]. Since the ionic radius of nitrogen $\left(r_{N}^{2+}=1.46 \AA\right)$ is larger than that of oxygen $\left(r_{O}^{2+}=1.38 \AA\right)$, the substitution of nitrogen in the O-site of the crystal structure may result in the $\mathrm{TiO}_{2}$ crystal lattice expanding because of tensile strain [42]. 


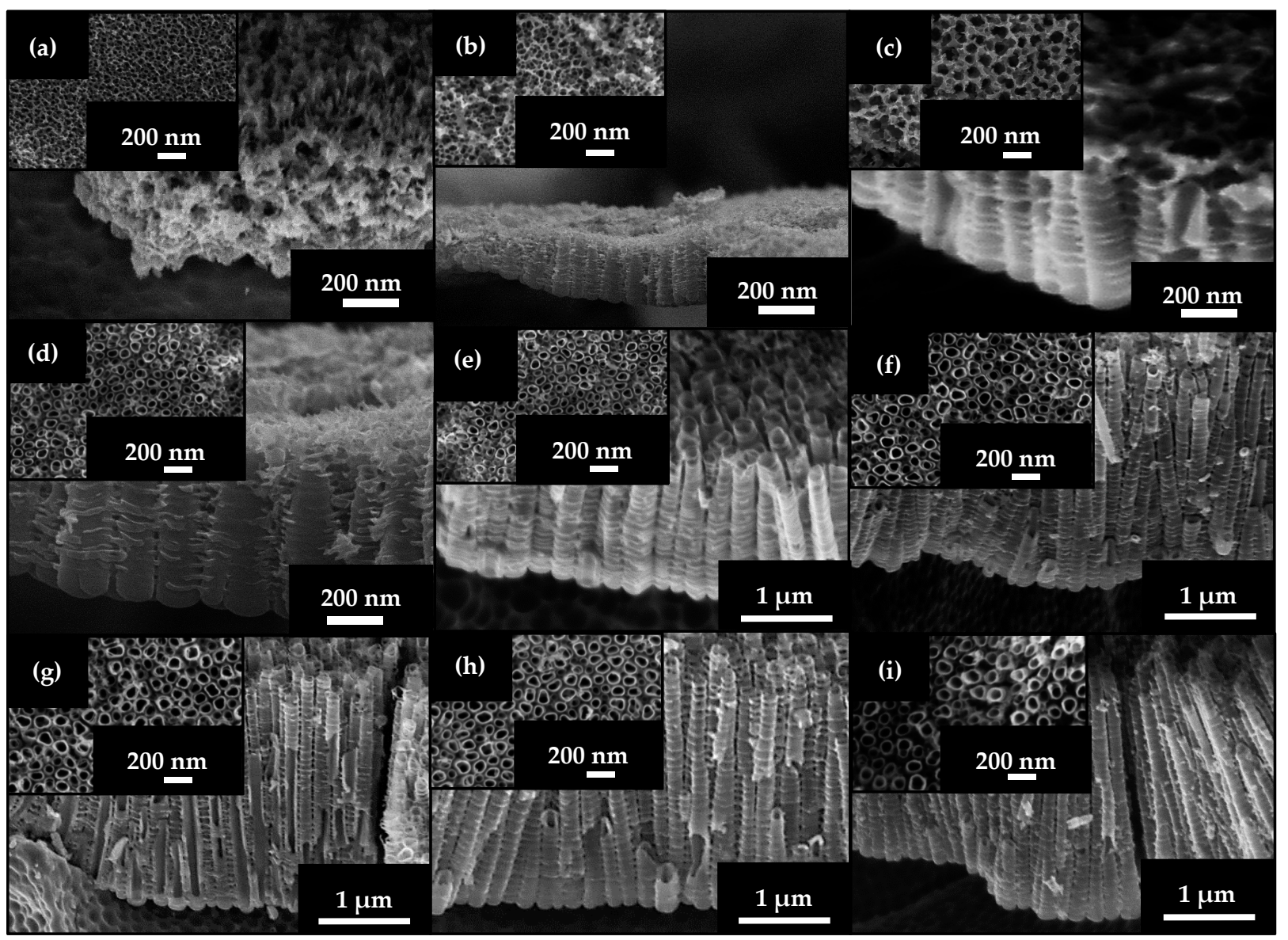

Figure 5. Figure 5. FESEM images of the anodized $\mathrm{TiO}_{2}$ at different anodization times: (a) 1, (b) 15, (c) 30, (d) 60, (e) 90, (f) 120, (g) 180, (h) 360 , and (i) $720 \mathrm{~min}$. All anodization was performed at $20 \mathrm{~V}$ in glycerol-water added to it $0.5 \mathrm{wt} . \% \mathrm{NH}_{4} \mathrm{~F}$.

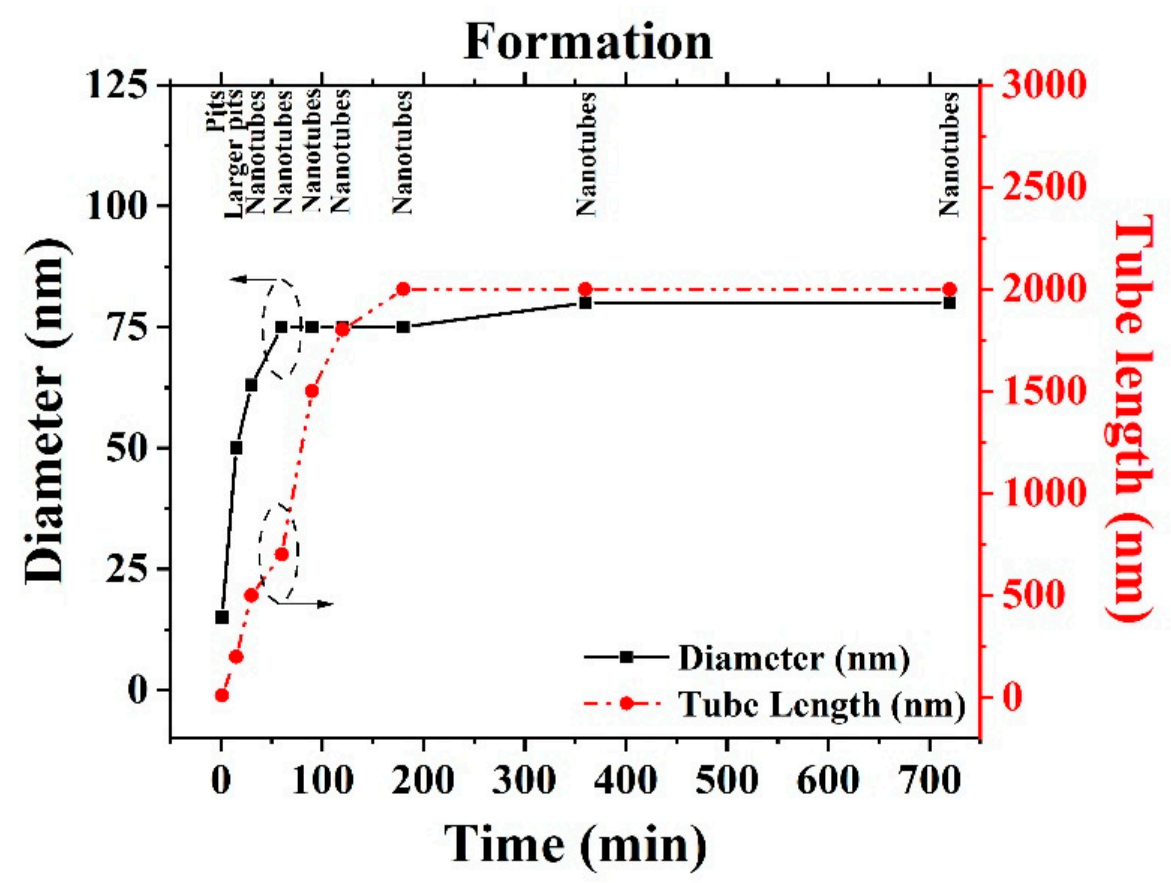

Figure 6. Titanium-dioxide $\left(\mathrm{TiO}_{2}\right)$ nanotube $(\mathrm{TNT})$ features formed $\left(\mathrm{NH}_{4} \mathrm{~F}=0.5 \mathrm{wt} . \%\right.$, voltage $\left.=20 \mathrm{~V}\right)$ for $1,15,30,60,90,120,180,360$, and $720 \mathrm{~min}$. All anodization was performed at $20 \mathrm{~V}$ in glycerol-water added to it $0.5 \mathrm{wt} . \% \mathrm{NH}_{4} \mathrm{~F}$. 


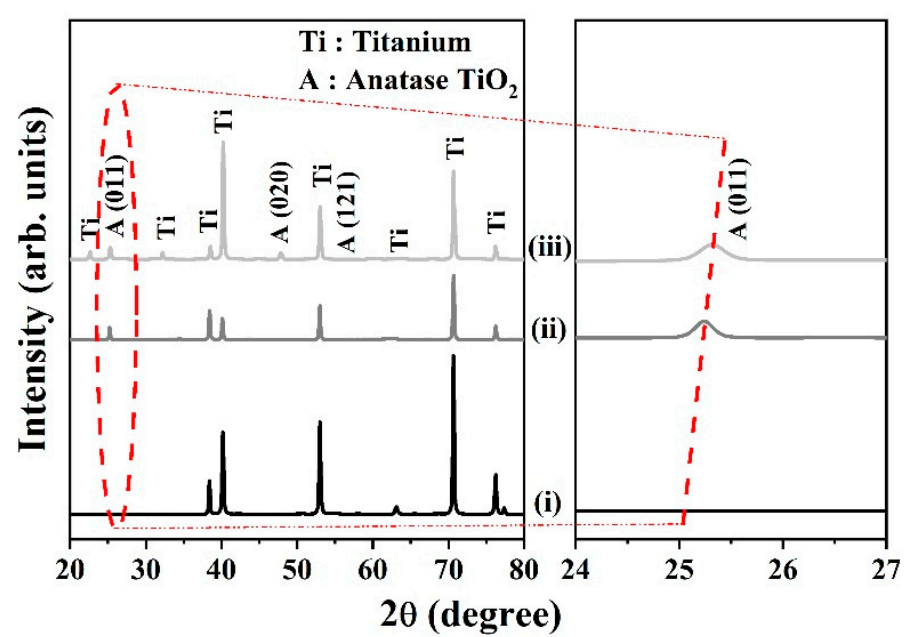

(a)

(b)

Figure 7. (a) XRD patterns for (i) as-anodized TNTs $(20 \mathrm{~V})$ and TNTs anodized in (ii) air and (iii) nitrogen. (b) Enlarged XRD patterns for anatase (011) peak. Annealing was conducted at $450{ }^{\circ} \mathrm{C}$ for $3 \mathrm{~h}$.

Anatase crystallite size for air- and nitrogen-annealed TNTs was calculated using the Debye-Scherrer equation at the (011) anatase peak according to the full width at the half maximum of the diffraction pattern. The crystallite sizes were 26.29 and $36.79 \mathrm{~nm}$ for nitrogen- and air-annealed TNTs, respectively. The smaller crystallite size for the nitrogenannealed TNTs can be attributed to growth suppression during annealing in the nitrogen environment [45].

To further study the changes in phase structure after annealing in air and nitrogen environment, Raman spectroscopy on the TNTs was carried out, and the results are shown in Figure 8. When the TNTs were annealed at $450{ }^{\circ} \mathrm{C}$, both samples exhibited three typical modes corresponding to $\mathrm{A}_{1 \mathrm{~g}}\left(515 \mathrm{~cm}^{-1}\right), \mathrm{B}_{1 \mathrm{~g}}\left(398\right.$ and $\left.515 \mathrm{~cm}^{-1}\right)$, and $\mathrm{E}_{\mathrm{g}}(144,197$, and $\left.640 \mathrm{~cm}^{-1}\right)$, respectively, in the Raman spectrum [39]. The peaks in these modes demonstrate the presence of anatase phase as the predominant crystal structure. The anatase peaks of TNT are labelled with A (Figure 8a). The intensity of the dominant anatase peak at $144 \mathrm{~cm}^{-1}$ was higher for the TNTs annealed in nitrogen compared to air. Moreover, from the enlarged image of the dominant peak in Figure $8 \mathrm{~b}$, it can be observed that the bandwidth increased for the nitrogen-annealed sample. These results indicate that the crystallinity of the anatase phase was enhanced and the crystallite size decreased after annealing in nitrogen, which is consistent with the results of the XRD measurement.

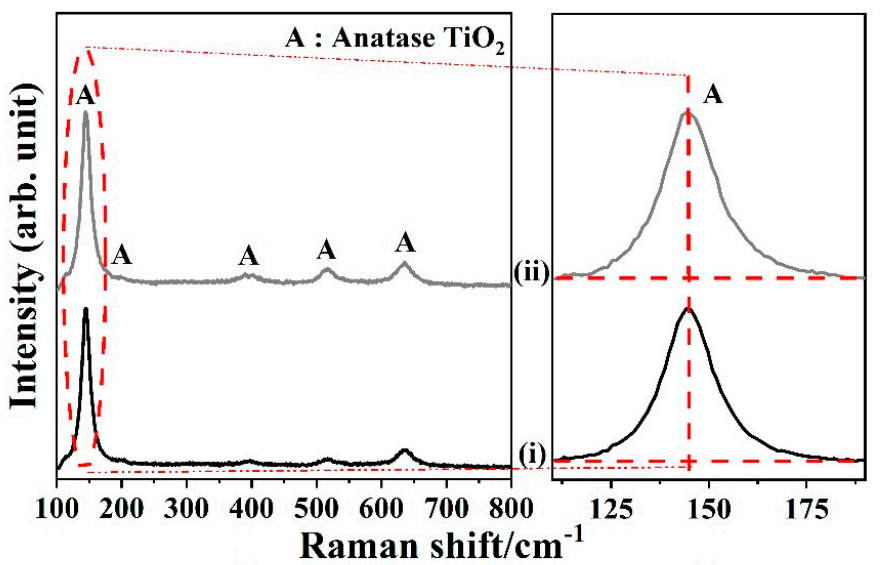

(a)

(b)

Figure 8. (a) Raman spectra for TNTs annealed in (i) air and (ii) nitrogen. (b) Enlarged Raman patterns for anatase peak at $144 \mathrm{~cm}^{-1}$. Annealing was conducted at $450{ }^{\circ} \mathrm{C}$ for $3 \mathrm{~h}$. 
The optical properties of the annealed TNT films were determined using diffuse reflectance UV-Vis spectroscopy, the results of which are shown in Figure 9. The energy bandgap $E_{g}$ of the samples was calculated using the Kubelka-Munk equation [46]:

$$
F(R)=\frac{(1-R)^{2}}{2 R}
$$

where $R$ is the diffuse reflectance of the sample. Using the Tauc relation, the following equation was obtained:

$$
F(R) h v=A\left(h v-E_{g}\right)^{n}
$$

where $A$ is the proportionality constant, $F(R)$ is the $\mathrm{K}-\mathrm{M}$ function, and $h v$ is photon energy $[47,48]$. The $F(R)$ function can be multiplied by $h v$ using a corresponding coefficient $(n)$. The $n$ values of 0.5 and 2 were used to estimate the direct and indirect bandgap oxide, respectively. Then, the extrapolation of $(F(R) \times h v)^{2}$ or $(F(R) \times h v)^{0.5}=0$ was conducted to obtain the direct and indirect $E_{g}$ values, respectively.

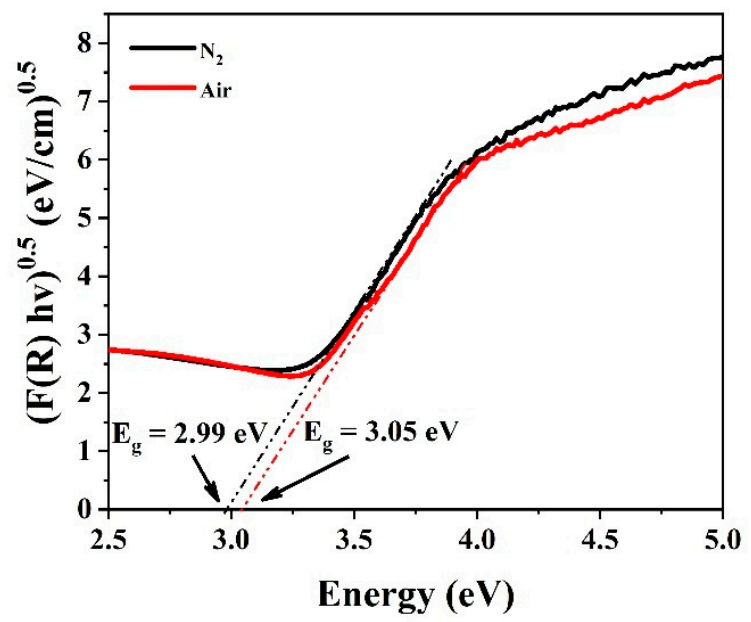

Figure 9. Experimental bandgap estimated using Kubelka-Munk diffuse reflectance solid state UV-Vis equation for TNTs annealed in nitrogen and air.

Figure 9 plots $(F(R) h v)^{0.5}$ vs. $h v$. Here, the indirect bandgap energy can be evaluated by extrapolating a straight line for $(F(R) h v)^{0.5}$ to intercept the photon energy axis (Figure 9) [49]. The estimated bandgaps obtained for the TNTs annealed in air and nitrogen are 3.05 and $2.99 \mathrm{eV}$, respectively. The smaller bandgap for nitrogen-annealed TNTs can be attributed to the presence of defect states within the bandgap [50].

\subsection{Photoreduction of Hexavalent Chromium Ions on Titanium-Dioxide Nanotubes}

$\mathrm{Cr}(\mathrm{VI})$ photoreduction experiments were conducted by exposing $10 \mathrm{ppm} \mathrm{Cr}(\mathrm{VI})$ solution to natural sunlight on a sunny day. $\mathrm{Cr}(\mathrm{VI})$ photoreduction was very slow without EDTA addition, as shown in Figure 10; less than $10 \% \mathrm{Cr}(\mathrm{VI})$ removal was recorded. The percentage of removal increased when EDTA was added to the $\mathrm{Cr}(\mathrm{VI})$ solution: $50 \%$ and $63 \%$ for air- and nitrogen-annealed TNTs, respectively, after $60 \mathrm{~min}$ of sunlight exposure. The total reduction of $\mathrm{Cr}(\mathrm{VI})$ was achieved for nitrogen-annealed TNTs after $120 \mathrm{~min}$ of sunlight exposure, possibly because of the narrow energy bandgap for this sample [46]. Air-annealed TNTs only achieved a 70\% reduction after $120 \mathrm{~min}$ of sunlight irradiation. 


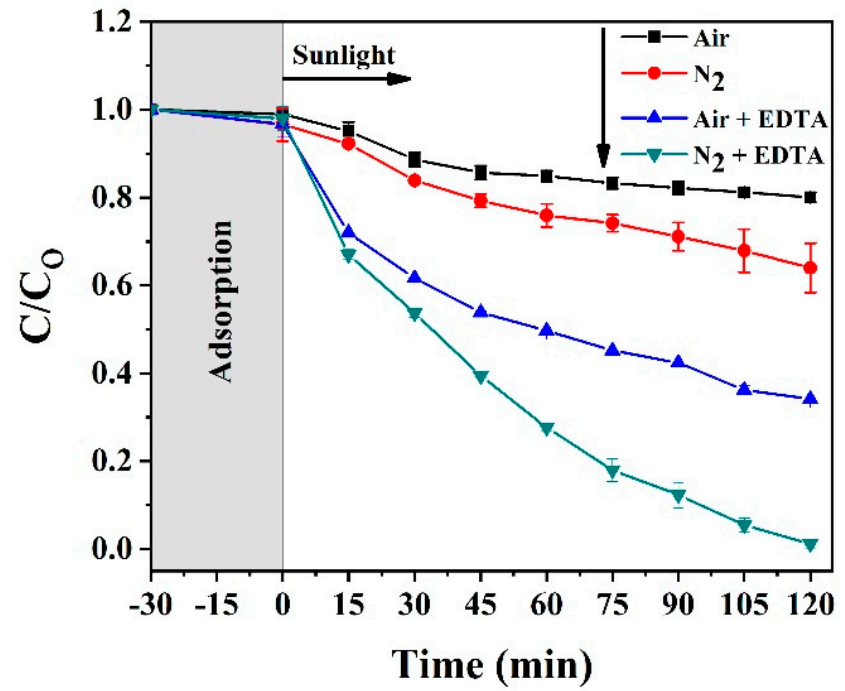

Figure 10. $\mathrm{Cr}(\mathrm{VI})$ removal efficiency of the TNTs annealed in nitrogen and air under natural sunlight irradiation $\left(\mathrm{Cr}(\mathrm{VI})\right.$ concentration $=10 \mathrm{ppm}, \mathrm{pH}=1$, sample $\left.=2 \mathrm{~cm}^{2}\right)$.

Nitrogen insertion is possible within the $\mathrm{TiO}_{2}$ lattice, as observed from the anatase peak shift in the XRD. Substituting nitrogen in the lattice resulted in the formation of N-2p states above the valence band (VB) of $\mathrm{TiO}_{2}[51]$, which reduced the $\mathrm{TiO}_{2}$ bandgap and thus enabled the adsorption of visible light for electron excitation (Equation (5)) from the $\mathrm{CB}$, as depicted in Figure 11.

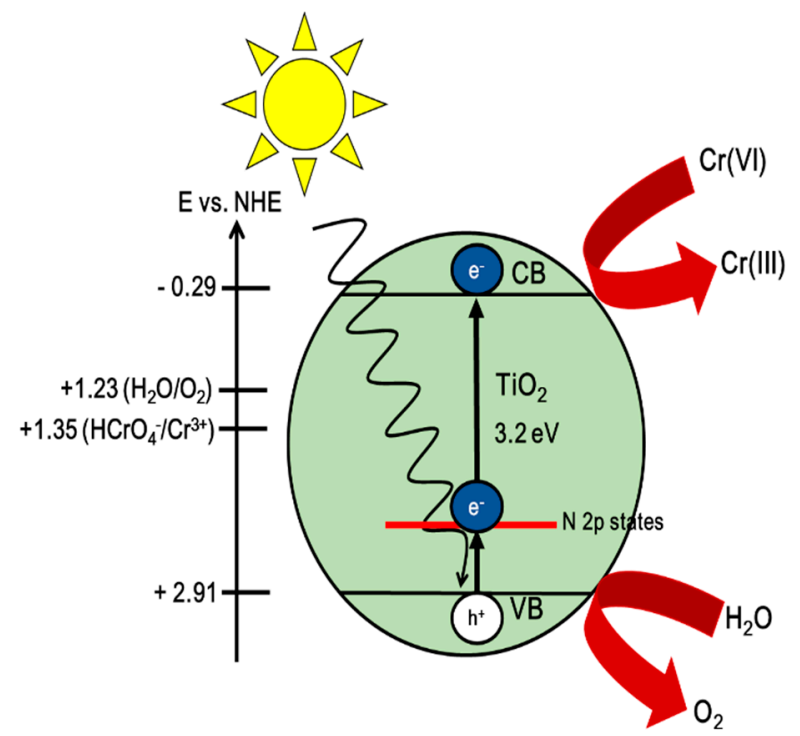

Figure 11. Proposed mechanism of $\mathrm{Cr}(\mathrm{VI})$ photoreduction of TNTs under sunlight irradiation.

The reduction potential of $\mathrm{HCrO}_{4}^{-} / \mathrm{Cr}^{3+}$ under the standard condition is $\mathrm{E}^{0}=+1.35 \mathrm{~V}$ vs. normal hydrogen electrode $(\mathrm{NHE})$ at $\mathrm{pH}=0$, whereas the $\mathrm{CB}$ potential for $\mathrm{TiO}_{2}$ is $+0.05 \mathrm{eV}$ vs. NHE at $\mathrm{pH}=0$ [52]. Since the reduction potential of $\mathrm{HCrO}_{4}{ }^{-} / \mathrm{Cr}^{3+}$ is more positive than the $\mathrm{CB}$, electron reduction is possible:

$$
\mathrm{TiO}_{2}+h v \rightarrow e_{C B}^{-}+h_{V B}^{+}
$$

The reduction of $\mathrm{Cr}(\mathrm{VI})$ under acidic conditions ( $\mathrm{pH} \leq 2)$ can be described in Equation (6) [53]:

$$
\mathrm{HCrO}_{4}^{-}+7 \mathrm{H}^{+}+3 e^{-} \rightarrow \mathrm{Cr}^{3+}+4 \mathrm{H}_{2} \mathrm{O}
$$


The band edge positions of the CB and VB for the TNTs was calculated by applying the concept of electronegativity using Equations (7) and (8):

$$
\begin{gathered}
E_{V B}=X-E_{e}+0.5 E_{g} \\
E_{C B}=E_{V B}-E_{g}
\end{gathered}
$$

where $E_{V B}$ is the VB edge potential at the point of zero charge, $E_{C B}$ is the CB edge potential, and $X$ is the absolute electronegativity of the semiconductor (the $X$ value for $\mathrm{TiO}_{2}$ is $5.81 \mathrm{eV}$ ) [54], which is defined as the geometric average of the absolute electronegativity of the constituent atoms, and $E_{e}$ is the energy of free electrons at the hydrogen scale (approximately $4.5 \mathrm{eV}$ ). Table 1 shows the calculated $E_{C B}, E_{V B}$, and $E_{g}$ values for TNTs formed in glycerol-water electrolyte and after annealing.

Table 1. Calculated $E_{C B}, E_{V B}$ and $E_{g}$ of TNTs annealed in nitrogen and air compared with anatase $\mathrm{TiO}_{2}$ from [55].

\begin{tabular}{cccc}
\hline Sample & $\boldsymbol{E}_{\boldsymbol{g}}(\mathbf{e V})$ & $\boldsymbol{E}_{\boldsymbol{V} \boldsymbol{B}}(\mathbf{e V})$ & $\boldsymbol{E}_{\boldsymbol{C B}}(\mathbf{e V})$ \\
\hline Anatase $\mathrm{TiO}_{2}$ & 3.20 & 2.91 & -0.29 \\
$\mathrm{TNTs}-\mathrm{Air}$ & 3.05 & 2.84 & -0.22 \\
$\mathrm{TNTs}_{2}$ & 2.99 & 2.81 & -0.19 \\
\hline
\end{tabular}

\subsubsection{Effect of EDTA as Hole Scavenger}

As shown in Figure 10, $\mathrm{Cr}(\mathrm{VI})$ reduction was sluggish without EDTA added to the solution. This could be due to several reasons, such as the fast recombination process [56] or the reoxidation of $\mathrm{Cr}(\mathrm{III})$ to $\mathrm{Cr}(\mathrm{VI})$ [57] by ${ }^{\bullet} \mathrm{OH}$. ${ }^{\bullet} \mathrm{OH}$ radicals are well known as a strong oxidizing agent and are produced when holes react with $\mathrm{H}_{2} \mathrm{O}$, which can be expressed by Equation (9) [58]:

$$
\mathrm{H}_{2} \mathrm{O}+h^{+} \rightarrow \bullet \mathrm{OH}+\mathrm{H}^{+}
$$

- $\mathrm{OH}$ concentration can be suppressed by ensuring they react with EDTA, as this results in their degradation to $\mathrm{CO}_{2}$ and $\mathrm{H}_{2} \mathrm{O}$, which can be expressed by Equation (10):

$$
\bullet \mathrm{OH}+\text { scavenger } \rightarrow \ldots \rightarrow \mathrm{CO}_{2}+\mathrm{H}_{2} \mathrm{O}
$$

Holes are also known to be oxidizing, and EDTA can be used to capture holes; capturing holes can also reduce the recombination of electron-hole pairs. This can be expressed by Equation (11):

$$
h^{+}+\text {scavenger } \rightarrow \ldots \rightarrow \mathrm{CO}_{2}+\mathrm{H}_{2} \mathrm{O}
$$

\subsubsection{The Effect of Initial Hexavalent Chromium Concentration}

A reduction experiment using $\mathrm{Cr}(\mathrm{VI})$ of varying concentration was performed using a $\mathrm{Cr}$ (VI) solution of 5, 10, 15, and $20 \mathrm{ppm}$. The experiment (Figure 12) showed a very fast reduction of $5 \mathrm{ppm} \mathrm{Cr}(\mathrm{VI})$ solution with $100 \%$ reduction after $90 \mathrm{~min}$ of sunlight exposure. As shown previously, 100\% removal of $\mathrm{Cr}(\mathrm{VI})$ was observed after $120 \mathrm{~min}$ for $10 \mathrm{ppm}$ solution. At higher ppm level of $\mathrm{Cr}$ (VI) reduction times, $80 \%$ removal was seen for $15 \mathrm{ppm}$ solution and $75 \%$ for 20 ppm solution.

\subsubsection{Reaction Kinetics Modeling}

The pseudo-first-order Langmuir-Hinshelwood model [59] was used to understand the reaction kinetics:

$$
R=-\frac{d C}{d t}=k t
$$


The resulting integrals of Equation (12) can be expressed as a pseudo-first-order equation when the adsorption is relatively weak/or the reactant concentration is low:

$$
-\ln \frac{C}{C_{0}}=k t
$$

where $R$ denotes the photocatalytic reaction rate; $k$ is the apparent photocatalytic pseudofirst-order reaction rate constant; $C_{o}$ and $C$ denote the initial $\mathrm{Cr}(\mathrm{VI})$ concentration and the $\mathrm{Cr}(\mathrm{VI})$ concentration at a given time $t$, respectively. The model validity is determined by the correlation coefficient of determination $\left(R^{2}\right)$ : a value close to 1 suggests that the model is ideal for explaining $\mathrm{Cr}(\mathrm{VI})$ kinetics. Figure 13 plots $-\ln \frac{\mathrm{C}}{\mathrm{C}_{0}}$ vs. time; the $k$ value is the slope of the line fitted on the plot of $-\ln \frac{C}{C_{o}}$ vs. $t$.

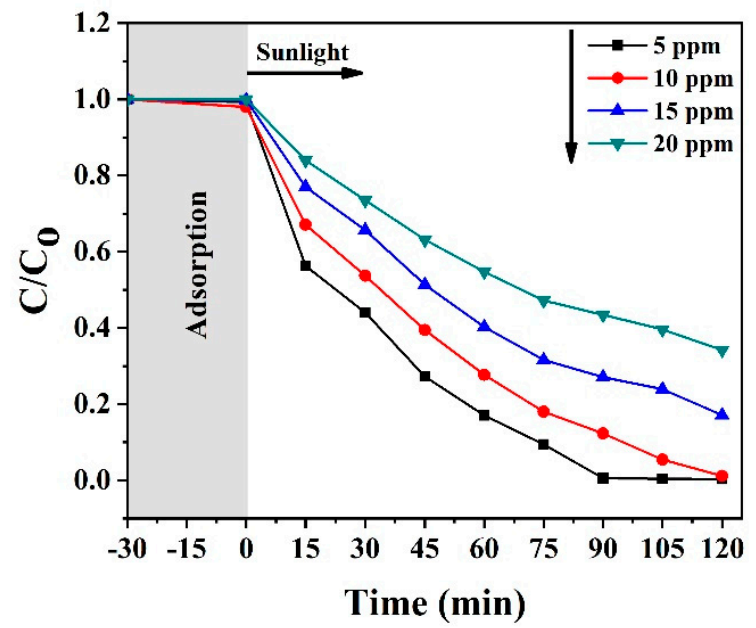

Figure 12. Photoreduction efficiency of nitrogen-annealed TNTs with EDTA and different Cr(VI) concentrations under natural sunlight for $120 \mathrm{~min}$.

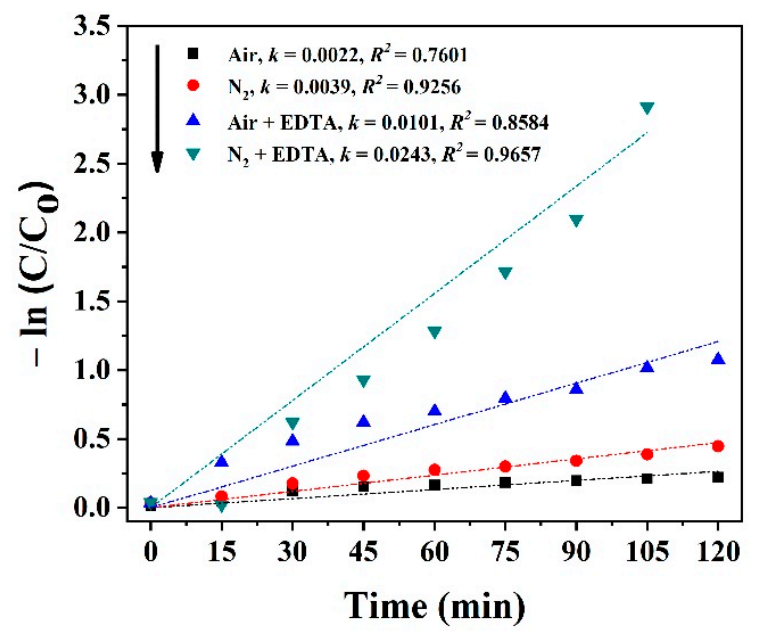

(a)

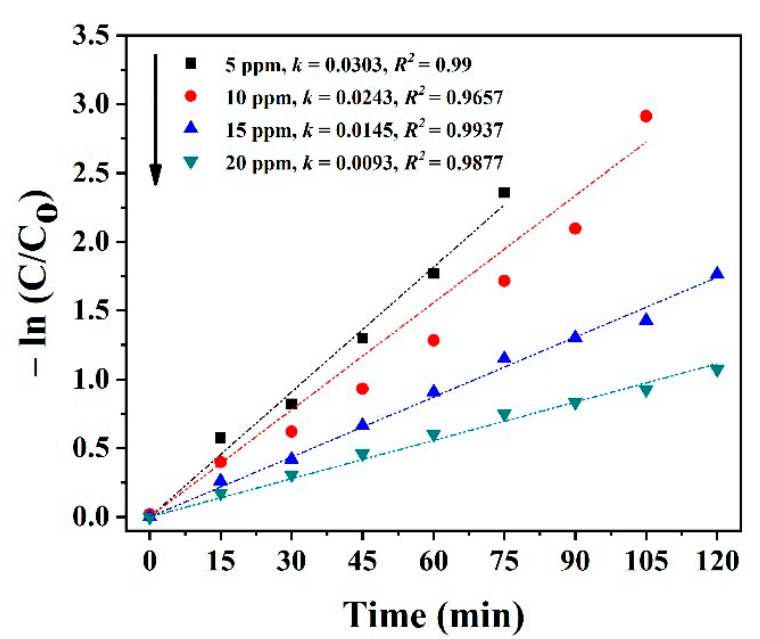

(b)

Figure 13. (a) Graph of $-\ln \left(C / C_{o}\right)$ vs. time and the reduction reaction rate constants for TNTs annealed in air and nitrogen with and without EDTA. (b) Graph of $-\ln \left(C / C_{0}\right)$ for reduction of $\mathrm{Cr}(\mathrm{VI})$ in various initial concentrations. Both experiments were conducted by sunlight irradiation for a $\mathrm{Cr}(\mathrm{VI})$ solution with a $\mathrm{pH}$ level of 1 .

The inset of Figure 13a provides the $k$ and $R^{2}$ values for $\mathrm{Cr}(\mathrm{VI})$ metal ions. The pseudofirst-order $\mathrm{Cr}(\mathrm{VI})$ removal rate increases when EDTA is introduced. Based on the $k$ value, the photocatalytic activity of nitrogen-annealed TNTs with EDTA as a hole scavenger is roughly seven times larger $\left(k=0.0249 \mathrm{~min}^{-1}\right)$ than that for nitrogen-annealed TNTs without EDTA $\left(k=0.0039 \mathrm{~min}^{-1}\right)$. Similar results were obtained for the $k$ value of air-annealed 
TNTs with EDTA $\left(k=0.0101 \mathrm{~min}^{-1}\right)$ : photocatalytic activity was roughly five times greater than it was in the absence of EDTA as a hole scavenger $\left(k=0.0022 \mathrm{~min}^{-1}\right)$.

For $\mathrm{Cr}(\mathrm{VI})$ solutions with different concentrations, $\mathrm{Cr}(\mathrm{VI})$ reduction appears to follow the Langmuir-Hinshelwood model and can be described by pseudo-first-order kinetics, as confirmed by the obtained straight line and $R^{2}$ value of $\cong 1$ (Figure $13 \mathrm{~b}$ ). A similar observation was reported for $\mathrm{Cr}(\mathrm{VI})$ photoreduction by Shaban et al. [60]. The reaction rate constant for $\mathrm{Cr}(\mathrm{VI})$ reduction was $0.0303,0.0243,0.0145$, and $0.0093 \mathrm{~min}^{-1}$ for the 5 , 10,15 , and $20 \mathrm{ppm}$ solutions, indicating a fast reduction in diluted solutions after sunlight irradiation for $120 \mathrm{~min}$.

Table 2 compares the $\mathrm{Cr}(\mathrm{VI})$ reduction efficiency obtained in the present paper with the existing literature, from which it is evident that the photocatalytic reduction of nitrogenannealed TNTs is comparable with fluorine- and carbon-doped TNTs under UV-Vis light irradiation [45,61-65]. Furthermore, by adding a small amount of EDTA (1 mM), a higher efficiency of $\mathrm{Cr}(\mathrm{VI})$ photoreduction was obtained compared to the addition of other scavengers, such as phenol $(10 \mathrm{mM})$ and tartaric acid $(6 \mathrm{mM})$, at higher amounts under UV-Vis light irradiation. [60,66,67].

Table 2. Comparison of obtained $\mathrm{Cr}(\mathrm{VI})$ reduction efficiency with recent studies under UV-Vis light irradiation ( $\mathrm{RGO}=$ reduced graphene oxide; $\mathrm{C}=$ carbon; $\mathrm{N}_{2}=$ nitrogen $)$.

\begin{tabular}{|c|c|c|c|c|c|c|c|c|c|}
\hline Photocatalyst & Method & $\begin{array}{c}\text { Sample } \\
\text { Size }\end{array}$ & Scavenger & $\mathrm{pH}$ & $\begin{array}{l}\text { Cr(VI) Conc. } \\
\text { (ppm) }\end{array}$ & $\begin{array}{c}\text { Source of } \\
\text { Light }\end{array}$ & $\begin{array}{c}\text { Removal } \\
\text { Efficiency (\%) }\end{array}$ & $\begin{array}{l}\text { Time } \\
\text { (h) }\end{array}$ & Ref. \\
\hline TNTs-N 2 & Anodization & $1 \mathrm{~cm}^{2}$ & - & 2 & 5 & $\begin{array}{l}\text { Natural } \\
\text { sunlight }\end{array}$ & 80 & 5 & [45] \\
\hline TNTs-Air & Anodization & $1 \mathrm{~cm}^{2}$ & - & 2 & 10 & $\begin{array}{l}\text { Natural } \\
\text { sunlight }\end{array}$ & 10 & 3 & {$[61]$} \\
\hline TNTs- $\mathrm{N}_{2}$ & Anodization & $2 \mathrm{~cm}^{2}$ & - & 1 & 10 & $\begin{array}{l}\text { Natural } \\
\text { sunlight }\end{array}$ & 37 & 2 & $\begin{array}{c}\text { Current } \\
\text { work }\end{array}$ \\
\hline $\begin{array}{l}\text { TNTs- } \\
\text { Fluorine }\end{array}$ & Sol-gel & - & - & 2.5 & 8 & $\begin{array}{l}\text { Fluorescent } \\
\text { lamp }\end{array}$ & 90 & 2 & {$[62]$} \\
\hline $\begin{array}{c}\mathrm{TiO}_{2^{-}} \\
5 \% \mathrm{RGO}\end{array}$ & Hydrothermal & - & - & 2 & 10 & Solar & 98 & 3 & [63] \\
\hline $\mathrm{TiO}_{2} / \mathrm{RGO}$ & Sol-gel & - & - & 2.6 & 12 & $\begin{array}{l}\text { Mercury } \\
\text { lamp }\end{array}$ & 86.5 & 4 & {$[64]$} \\
\hline $\begin{array}{c}0.30 w t . \% F e- \\
\text { N-C-TiO }\end{array}$ & Hydrothermal & - & - & 2 & 20 & $\begin{array}{l}\text { Xenon } \\
\text { lamp }\end{array}$ & 100 & 4 & [65] \\
\hline $\begin{array}{c}\text { C-Modified } \\
\text { n- }-\mathrm{TiO}_{2}\end{array}$ & Sol-gel & - & $\begin{array}{l}\text { Phenol } \\
(10 \mathrm{mM})\end{array}$ & 5 & 5 & $\begin{array}{l}\text { Natural } \\
\text { sunlight }\end{array}$ & 100 & 0.33 & {$[60]$} \\
\hline $\begin{array}{l}\mathrm{TiO}_{2} \mathrm{NW}- \\
\mathrm{RGO}\end{array}$ & Anodization & $4 \mathrm{~cm}^{2}$ & $\begin{array}{c}\text { EDTA } \\
(1 \mathrm{mM})\end{array}$ & 1 & 10 & $\begin{array}{l}\text { Xenon } \\
\text { lamp }\end{array}$ & 100 & 1 & [66] \\
\hline $\begin{array}{c}\text { P25 } \\
\text { Degussa }\end{array}$ & - & - & $\begin{array}{l}\text { Tartaric acid } \\
\quad(6 \mathrm{mM})\end{array}$ & 2.2 & 20 & $\begin{array}{l}\text { Natural } \\
\text { sunlight }\end{array}$ & 100 & 2 & [67] \\
\hline TNTs-N 2 & Anodization & $2 \mathrm{~cm}^{2}$ & $\begin{array}{c}\text { EDTA } \\
(1 \mathrm{mM})\end{array}$ & 1 & 10 & $\begin{array}{l}\text { Natural } \\
\text { sunlight }\end{array}$ & 100 & 2 & $\begin{array}{c}\text { Current } \\
\text { work }\end{array}$ \\
\hline
\end{tabular}

\section{Materials and Methods}

Ti foils (99.96\% pure; thickness: $0.13 \mathrm{~mm}$; Stream Chemical, Newburyport, USA) were cut into square sections $(10 \times 10 \mathrm{~mm})$ for the experiment. Before anodization, the foils were degreased in an ultrasonic bath of acetone (J.T. Baker-9254, Center Valley, PA, United States) and then ethanol (95.7\% pure; Samchen, Shah Alam, Selangor, Malaysia) for $15 \mathrm{~min}$ each. The foils were then rinsed with deionized water and dried. The cleaned foils were then placed in an electrochemical cell with a restricted area of $5 \times 10 \mathrm{~mm}$ exposed to the electrolyte. The anodization experiment was conducted using a two-electrode 
electrochemical cell at room temperature with a platinum cathode (diameter of $2 \mathrm{~mm}$; $75 \mathrm{~mm}$ in length; Metrohm, Herisau, Switzerland) and Ti foil as the anode using a DC power source (Agilent E3647A, Santa Clara, CA, USA). The distance between the anode and cathode was $30 \mathrm{~mm}$. The electrolyte was a glycerol-water ( $85 \%$ and $15 \%$, respectively) solution (Merck, Darmstadt, Germany). Ammonium fluoride $\left(\mathrm{NH}_{4} \mathrm{~F}\right.$, Merck, Darmstadt, Germany)) was added to the electrolyte in different amounts: $0.1,0.3,0.5,0.7,0.9$, and $1.0 \mathrm{wt} . \%$. To examine the anodization time effect, a $0.5 \mathrm{wt} . \% \mathrm{NH}_{4} \mathrm{~F}$ electrolyte bath was used. The anodization time varied from 1 to $720 \mathrm{~min}$ at a constant voltage of $20 \mathrm{~V}$. The effect of the anodization voltage was examined by varying the voltage from 1 to $80 \mathrm{~V}$ for 90 min in the same electrolyte bath (fixed sweep rate of $0.1 \mathrm{~V} / \mathrm{s}$ ).

The anodized Ti foil was removed from the electrolyte and rinsed with deionized water and dried in air naturally. The anodized Ti was then annealed using a horizontal tube furnace (Lenton 1200, Derbyshire, United Kingdom) at $450{ }^{\circ} \mathrm{C}$ for $3 \mathrm{~h}$ in air or nitrogen. The morphologies of the anodized foils were observed by field emission scanning electron microscopy (FESEM; Variable Pressure Zeiss Supra 35, Oberkochen, Germany). Transmission electron microscopy (TEM; JEOL, JEM-2100F, Tokyo, Japan), at an acceleration voltage of $200 \mathrm{kV}$, was used to provide detailed observations of nanotube structure. X-ray diffraction (XRD; Bruker D8, Bruker GmBH, Karlsruhe, Germany) and Raman spectrometer (RENISHAW inVia 9P1567, Charfield, United Kingdom) were conducted to determine the TNT phase and crystal analysis. UV-visible (UV-Vis) spectrophotometers were used to attain the diffuse reflectance spectra (Cary 5000, UV-Vis-NIR, Agilent, Santa Clara, United States) and conduct the $\mathrm{Cr}(\mathrm{VI})$ photoreduction (Varian Cary 50, budd lake, NJ, United States).

For the $\mathrm{Cr}(\mathrm{VI})$ removal evaluation, $100 \mathrm{ppm} \mathrm{Cr}(\mathrm{VI})$ was prepared by dissolving $0.0283 \mathrm{~g}$ of potassium dichromate salt $\left(\mathrm{K}_{2} \mathrm{Cr}_{2} \mathrm{O}_{7}\right.$, A.R. grade, Merck, Germany) in $100 \mathrm{~mL}$ of deionized water. Then, the $\mathrm{Cr}(\mathrm{VI})$ stock solution was diluted to obtain the 5-20 ppm $\mathrm{Cr}(\mathrm{VI})$ solution. The $\mathrm{pH}$ of the solution was lowered using hydrogen chloride (Merck, Germany). For the hole scavenger, $1 \mathrm{mM}$ of Ethylenediaminetetraacetic acid (EDTA; AJAX Chemicals, Sydney, Australia) was added to the $\mathrm{Cr}(\mathrm{VI})$ solution. During the test, four anodized foils with a surface area of $1 \times 0.5 \mathrm{~cm}^{2}$ were immersed in the $\mathrm{Cr}(\mathrm{VI})$ solution. Before light irradiation, the solution was left in the dark for $30 \mathrm{~min}$ to achieve adsorptiondesorption equilibrium. The solution was then exposed to sunlight with an average light intensity of $\sim 1000 \mathrm{Wm}^{-2}$, which was measured with a solar power meter (TM-207, Tenmars, Taiwan, China). During light irradiation, $2 \mathrm{~mL}$ of the aliquot sample was withdrawn every $15 \mathrm{~min}$. The reduction of $\mathrm{Cr}(\mathrm{VI})$ was determined using 1,5-diphenylcarbazide (Merck, Germany), and, based on the UV-Vis results, the $\mathrm{Cr}(\mathrm{VI})$ concentration in the solution was calculated using Equation (14) at $\lambda_{\max }=540 \mathrm{~nm}$ :

$$
\mathrm{Cr}(\mathrm{VI}) \text { removal efficiency }=\frac{C}{C_{0}}
$$

where $C$ denotes the concentration of $\mathrm{Cr}(\mathrm{VI})$ at a given time (at $\lambda_{\max }=540 \mathrm{~nm}$ ), and $C_{o}$ is the initial concentration (before sunlight irradiation).

\section{Conclusions}

In this study, photoreduction of $\mathrm{Cr}(\mathrm{VI})$ using anodized TNTs under natural sunlight irradiation was demonstrated. The TNTs were formed by the anodic oxidation of Ti foil in a fluorinated glycerol-water electrolyte. The effects of $\mathrm{NH}_{4} \mathrm{~F}$ concentration in the electrolyte, anodization voltage, anodization duration, and annealing atmosphere (air or nitrogen) on the nanotubes were systematically described. The minimum voltage for TNTs formation was identifiezd as $5 \mathrm{~V}$. To obtain TNT arrays with a clear, open top structure exhibiting a considerable length, anodization must be conducted using an electrolyte with an $\mathrm{NH}_{4} \mathrm{~F}$ concentration of $>0.5 \mathrm{wt} . \%$ for more than $30 \mathrm{~min}$. A higher $\mathrm{NH}_{4} \mathrm{~F}$ content led to rigorous etching forming irregular TNTs. The diameter of the TNT formed increased with voltage in the range of 10 to $60 \mathrm{~V}$, while anodization at $80 \mathrm{~V}$ resulted in the collapse of the tubular structure. TNTs with an average length of $\sim 2 \mu \mathrm{m}$ were obtained after anodization for 
180 min using an applied voltage of $20 \mathrm{~V}$. From the XRD results of the annealed sample in air and nitrogen, the anatase crystallite size obtained was 36.79 and $26.29 \mathrm{~nm}$, respectively. The smaller crystallite size of nitrogen-annealed TNTs is consistent with the obtained Raman results. The bandgaps of both annealed samples were determined using UV-Vis DRS, indicating a smaller bandgap for the nitrogen-annealed TNTs compared to the airannealed ones. This enabled an enhanced $\mathrm{Cr}(\mathrm{VI})$ photoreduction efficiency in the visible light region, especially under natural sunlight irradiation. This was further demonstrated by the reduction of $10 \mathrm{ppm} \mathrm{Cr}(\mathrm{VI})$ solution that achieved a complete $(100 \%)$ removal after 120 min of exposure to natural sunlight with the addition of EDTA as a hole scavenger.

Author Contributions: Conceptualization, S.A.R., N.A. and Z.L.; methodology, S.A.R. and Z.L.; validation, S.A.R., W.K.T., G.K., A.M. and Z.L.; formal analysis, S.A.R., N.A. and Z.L.; investigation, S.A.R., N.A. and Z.L.; resources, Z.L. and W.K.T.; data curation, S.A.R. and Z.L.; writing-original draft preparation, S.A.R.; writing-review and editing, S.A.R., W.K.T. and Z.L.; visualization, S.A.R., N.B. and S.I.; supervision, Z.L.; project administration, W.K.T. and Z.L.; funding acquisition, W.K.T. and Z.L. All authors have read and agreed to the published version of the manuscript.

Funding: This research was funded by the Research University Grant (USM-TUT Collaboration) 1001/PBAHAN/870048.

Data Availability Statement: Not applicable.

Acknowledgments: Research University Grant (USM-TUT Collaboration) 1001/PBAHAN/870048 and support from Universiti Teknologi MARA are also acknowledged. W. K Tan acknowledges the Japan society for KAKENHI Early-Career Scientist JP18K14013 for supporting this research.

Conflicts of Interest: The authors declare no conflict of interest.

\section{References}

1. Karimi-Maleh, H.; Orooji, Y.; Ayati, A.; Qanbari, S.; Tanhaei, B.; Karimi, F.; Alizadeh, M.; Rouhi, J.; Fu, L.; Sillanpää, M. Recent advances in removal techniques of $\mathrm{Cr}(\mathrm{VI})$ toxic ion from aqueous solution: A comprehensive review. J. Mol. Liq. 2020, 329 , 115062. [CrossRef]

2. Schrank, S.G.; José, H.J.; Moreira, R.F.P.M. Simultaneous photocatalytic $\mathrm{Cr}(\mathrm{VI})$ reduction and dye oxidation in a $\mathrm{TiO}_{2}$ slurry reactor. J. Photochem. Photobiol. A Chem. 2002, 147, 71-76. [CrossRef]

3. Shahid, M.; Shamshad, S.; Rafiq, M.; Khalid, S.; Bibi, I.; Niazi, N.K.; Dumat, C.; Rashid, M.I. Chromium speciation, bioavailability, uptake, toxicity and detoxification in soil-plant system: A review. Chemosphere 2017, 178, 513-533. [CrossRef] [PubMed]

4. Rudzi, S.K.; Ho, Y.B.; Abd Khani, I.I. Heavy metals contamination in paddy soil and water and associated dermal health risk among farmers. Malays. J. Med. Health Sci. 2018, 14, 2-10.

5. Hoyer, P. Formation of a titanium dioxide nanotube array. Langmuir 1996, 12, 1411-1413. [CrossRef]

6. Tu, Y.F.; Huang, S.Y.; Sang, J.P.; Zou, X.W. Synthesis and photocatalytic properties of Sn-Doped $\mathrm{TiO}_{2}$ nanotube arrays. J. Alloys Compd. 2009, 482, 382-387. [CrossRef]

7. Yuan, Z.-Y.; Su, B.-L. Titanium oxide nanotubes, nanofibers and nanowires. Colloids Surf. A Physicochem. Eng. Asp. 2004, 241, 173-183. [CrossRef]

8. Kasuga, T.; Hiramatsu, M.; Hoson, A.; Sekino, T.; Niihara, K. Titania nanotubes prepared by chemical processing. Adv. Mater. 1999, 11, 1307-1311. [CrossRef]

9. Abaffy, N.B.; Evans, P.; Triani, G.; McCulloch, D. Multilayer alumina and titania optical coatings prepared by atomic layer deposition. Nanostruct. Thin Films 2008, 7041, 704109. [CrossRef]

10. Yoshimura, N.; Sato, S.; Itoi, M.; Taguchi, H. Electrical properties of $\mathrm{TiO}_{2}$ thin film prepared by sol-gel method. IEEJ Trans. Fundam. Mater. 1991, 111, 117-122. [CrossRef]

11. Venkatachalam, N.; Palanichamy, M.; Murugesan, V. Sol-gel preparation and characterization of nanosize $\mathrm{TiO}_{2}$ : Its photocatalytic performance. Mater. Chem. Phys. 2007, 104, 454-459. [CrossRef]

12. Zhao, J.; Wang, X.; Chen, R.; Li, L. Fabrication of titanium oxide nanotube arrays by anodic oxidation. Solid State Commun. 2005, 134, 705-710. [CrossRef]

13. Zwilling, V.; Darque-Ceretti, E.; Boutry-Forveille, A.; David, D.; Perrin, M.Y.; Aucouturier, M. Structure and Physicochemistry of anodic oxide films on titanium and TA6V alloy. Surf. Interface Anal. 1999, 27, 629-637. [CrossRef]

14. Krengvirat, W.; Sreekantan, S.; Noor, A.-F.M.; Negishi, N.; Kawamura, G.; Muto, H.; Matsuda, A. Low-temperature crystallization of $\mathrm{TiO}_{2}$ nanotube arrays via hot water treatment and their photocatalytic properties under visible-light irradiation. Mater. Chem. Phys. 2013, 137, 991-998. [CrossRef] 
15. Krengvirat, W.; Sreekantan, S.; Noor, A.-F.M.; Kawamura, G.; Muto, H.; Matsuda, A. Single-step growth of carbon and potassiumembedded $\mathrm{TiO}_{2}$ nanotube arrays for efficient photoelectrochemical hydrogen generation. Electrochim. Acta 2013, 89, 585-593. [CrossRef]

16. Gong, D.; Grimes, C.A.; Varghese, O.K.; Hu, W.; Singh, R.S.; Chen, Z.; Dickey, E.C. Titanium oxide nanotube arrays prepared by anodic oxidation. J. Mater. Res. 2001, 16, 3331-3334. [CrossRef]

17. Choi, J.; Wehrspohn, R.B.; Lee, J.; Gösele, U. Anodization of nanoimprinted titanium: A comparison with formation of porous alumina. Electrochim. Acta 2004, 49, 2645-2652. [CrossRef]

18. Macák, J.M.; Tsuchiya, H.; Schmuki, P. High-aspect-ratio $\mathrm{TiO}_{2}$ nanotubes by anodization of titanium. Angew. Chem. Int. Ed. 2005, 44, 2100-2102. [CrossRef] [PubMed]

19. Tsuchiya, H.; Akaki, T.; Nakata, J.; Terada, D.; Tsuji, N.; Koizumi, Y.; Minamino, Y.; Schmuki, P.; Fujimoto, S. Metallurgical aspects on the formation of self-organized anodic oxide nanotube layers. Electrochim. Acta 2009, 54, 5155-5162. [CrossRef]

20. Lockman, Z.; Sreekantan, S.; Ismail, S.; Schmidt-Mende, L.; MacManus-Driscoll, J.L. Influence of anodisation voltage on the dimension of Titania nanotubes. J. Alloys Compd. 2010, 503, 359-364. [CrossRef]

21. Sreekantan, S.; Lockman, Z.; Hazan, R.; Tasbihi, M.; Tong, L.K.; Mohamed, A.R. Influence of electrolyte $\mathrm{pH}$ on TiO 2 nanotube formation by Ti anodization. J. Alloys Compd. 2009, 485, 478-483. [CrossRef]

22. Kawamura, G.; Ohmi, H.; Tan, W.K.; Lockman, Z.; Muto, H.; Matsuda, A. Ag nanoparticle-deposited TiO $\mathrm{T}_{2}$ nanotube arrays for electrodes of Dye-sensitized solar cells. Nanoscale Res. Lett. 2015, 10, 219. [CrossRef]

23. Lockman, Z.; Ismail, S.; Sreekantan, S.; Schmidt-Mende, L.; MacManus-Driscoll, J.L. The rapid growth of $3 \mu \mathrm{m}$ long titania nanotubes by anodization of titanium in a neutral electrochemical bath. Nanotechnology 2009, 21, 055601. [CrossRef] [PubMed]

24. Ismail, S.; Lockman, Z.; Ahmad, Z.A. Crystallization of $\mathrm{TiO}_{2}$ Nanotubes Arrays Grown by Anodization of Ti in Organic Electrolyte. Adv. Mater. Res. 2012, 620, 412-417. [CrossRef]

25. Sreekantan, S.; Saharudin, K.A.; Lockman, Z.; Tzu, T.W. Fast-rate formation of $\mathrm{TiO}_{2}$ nanotube arrays in an organic bath and their applications in photocatalysis. Nanotechnology 2010, 21, 365603. [CrossRef] [PubMed]

26. Regonini, D.; Satka, A.; Jaroenworaluck, A.; Allsopp, D.W.E.; Bowen, C.R.; Stevens, R. Factors influencing surface morphology of anodized $\mathrm{TiO}_{2}$ nanotubes. Electrochim. Acta 2012, 74, 244-253. [CrossRef]

27. Liu, Z.; Zhang, X.; Nishimoto, S.; Jin, M.; Tryk, D.A.; Murakami, T.; Fujishima, A. Highly ordered TiO 2 nanotube arrays with controllable length for photoelectrocatalytic degradation of phenol. J. Phys. Chem. C 2008, 112, 253-259. [CrossRef]

28. Perillo, P.M.; Rodriguez, D.F. Growth control of $\mathrm{TiO}_{2}$ nanotubes in different physical environments. Nanosci. Methods 2012, 1 , 194-200. [CrossRef]

29. Raja, K.; Gandhi, T.; Misra, M. Effect of water content of ethylene glycol as electrolyte for synthesis of ordered Titania nanotubes. Electrochem. Commun. 2007, 9, 1069-1076. [CrossRef]

30. Naghizadeh, S.G.H.A.; Golobostanfard, M.R. Effect of fluoride concentration and water content on morphology of Titania nanotubes in ethylene glycol solution. Adv. Mater. Res. 2014, 829, 907-911. [CrossRef]

31. Song, H.; Cheng, K.; Guo, H.; Wang, F.; Wang, J.; Zhu, N.; Bai, M.; Wang, X. Effect of ethylene glycol concentration on the morphology and catalytic properties of $\mathrm{TiO}_{2}$ nanotubes. Catal. Commun. 2017, 97, 23-26. [CrossRef]

32. Taib, M.A.A.; Razak, K.A.; Jaafar, M.; Lockman, Z. Initial growth study of $\mathrm{TiO}_{2}$ nanotube arrays anodised in $\mathrm{KOH} /$ fluoride/ethylene glycol electrolyte. Mater. Des. 2017, 128, 195-205. [CrossRef]

33. Nyein, N.; Tan, W.K.; Kawamura, G.; Matsuda, A.; Lockman, Z. Anodic Ag/ $\mathrm{TiO}_{2}$ nanotube array formation in NaOH/fluoride/ethylene glycol electrolyte as a photoanode for dye-sensitized solar cells. Nanotechnology 2016, 27, 355605. [CrossRef]

34. Nyein, N.; Tan, W.K.; Kawamura, G.; Matsuda, A.; Lockman, Z. $\mathrm{TiO}_{2}$ nanotube arrays formation in fluoride/ethylene glycol electrolyte containing $\mathrm{LiOH}$ or $\mathrm{KOH}$ as photoanode for dye-sensitized solar cell. J. Photochem. Photobiol. A Chem. 2017, 343, 33-39. [CrossRef]

35. Nyein, N.; Zulkifli, M.A.; Tan, W.K.; Matsuda, A.; Lockman, Z. Effect of $\mathrm{NaOH}$ Concentration on the formation of $\mathrm{TiO}_{2}$ nanotube arrays by anodic oxidation process for photoelectrochemical cell. Solid State Phenom. 2017, 264, 152-155. [CrossRef]

36. Taib, M.A.A.; Tan, W.K.; Okuno, T.; Kawamura, G.; Jaafar, M.; Razak, K.A.; Matsuda, A.; Lockman, Z. Formation of TiO 2 nanotube arrays by anodic oxidation in $\mathrm{LiOH}$ added ethylene glycol electrolyte and the effect of thermal annealing on the photoelectrochemical properties. In Proceedings of the International Conference on Nano-Electronic Technology Devices and Materials, 2015 (IC-NET 2015), Selangor, Malaysia, 27 February-2 March 2015; AIP Publishing LLC: Melville, NY, USA, 2016; Volume 1733, p. 020025.

37. Nyein, N.; Lockman, Z.; Matsuda, A.; Kawamura, G.; Tan, W.K.; Oo, T.Z. Formation of $\mathrm{TiO}_{2}$ nanotube arrays in KOH added fluoride-ethylene glycol (EG) electrolyte and its photoelectrochemical response. In Proceedings of the International Conference on Nano-Electronic Technology Devices and Materials, 2015 (IC-NET 2015), Selangor, Malaysia, 27 February-2 March 2015; AIP Publishing LLC: Melville, NY, USA, 2016; Volume 1733, p. 020030.

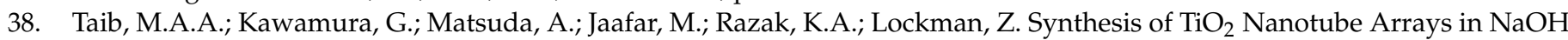
Added Ethylene Glycol Electrolyte and the Effect of Annealing Temperature on the Nanotube Arrays to their Photocurrent Performance. Key Eng. Mater. 2016, 701, 28-32. [CrossRef]

39. Taib, M.A.A.; Alias, N.; Jaafar, M.; Razak, K.A.; Tan, W.K.; Shahbudin, I.P.; Kawamura, G.; Matsuda, A.; Lockman, Z. Formation of grassy $\mathrm{TiO}_{2}$ nanotube thin film by anodisation in peroxide electrolyte for $\mathrm{Cr}(\mathrm{VI})$ removal under ultraviolet radiation. Nanotechnology 2020, 31, 435605. [CrossRef] 
40. Berger, S.; Albu, S.P.; Schmidt-Stein, F.; Hildebrand, H.; Schmuki, P.; Hammond, J.S.; Paul, D.F.; Reichlmaier, S. The origin for tubular growth of $\mathrm{TiO}_{2}$ nanotubes: A fluoride rich layer between tube-walls. Surf. Sci. 2011, 605, L57-L60. [CrossRef]

41. Sahai, A.; Kumar, Y.; Agarwal, V.; Olive-Méndez, S.F.; Goswami, N. Doping concentration driven morphological evolution of Fe doped ZnO nanostructures. J. Appl. Phys. 2014, 116, 164315. [CrossRef]

42. Kumari, R.; Sahai, A.; Goswami, N. Effect of nitrogen doping on structural and optical properties of ZnO nanoparticles. Prog. Nat. Sci. 2015, 25, 300-309. [CrossRef]

43. Ramirez, H.; Medina-Ramirez, I. Photocatalytic Semiconductors; Springer: New York, NY, USA, 2015; p. 117.

44. Morikawa, T.; Asahi, R.; Ohwaki, T.; Aoki, K.; Taga, Y. Band-gap narrowing of titanium dioxide by nitrogen doping. Jpn. J. Appl. Phys. 2001, 40, L561-L563. [CrossRef]

45. Zulkifli, M.A.; Bashirom, N.; Tan, W.K.; Kawamura, G.; Matsuda, A.; Lockman, Z. Rapid TiO 2 nanotubes formation in aged electrolyte and their application as photocatalysts for $\mathrm{Cr}(\mathrm{VI})$ reduction under visible light. IEEE Trans. Nanotechnol. 2018, 17, 1106-1110. [CrossRef]

46. Murphy, A. Band-gap determination from diffuse reflectance measurements of semiconductor films, and application to photoelectrochemical water-splitting. Sol. Energy Mater. Sol. Cells 2007, 91, 1326-1337. [CrossRef]

47. Tauc, J.; Grigorovici, R.; Vancu, A. Optical properties and electronic structure of amorphous germanium. Phys. Status Solidi B 1966, 15, 627-637. [CrossRef]

48. Davis, E.A.; Mott, N.F. Conduction in non-crystalline systems V. Conductivity, optical absorption and photoconductivity in amorphous semiconductors. Philos. Mag. 1970, 22, 0903-0922. [CrossRef]

49. López, R.; Gómez, R. Band-gap energy estimation from diffuse reflectance measurements on sol-gel and commercial TiO 2 : A comparative study. J. Sol-Gel Sci. Technol. 2012, 61, 1-7. [CrossRef]

50. Delegan, N.; Daghrir, R.; Drogui, P.; El Khakani, M.A. Bandgap tailoring of in-situ nitrogen-doped $\mathrm{TiO}_{2}$ sputtered films intended for electrophotocatalytic applications under solar light. J. Appl. Phys. 2014, 116, 153510. [CrossRef]

51. Wang, W.; Tadé, M.O.; Shao, Z. Nitrogen-doped simple and complex oxides for photocatalysis: A review. Prog. Mater. Sci. 2018, 92, 33-63. [CrossRef]

52. Sayama, K.; Arakawa, H. Photocatalytic decomposition of water and photocatalytic reduction of carbon dioxide over zirconia catalyst. J. Phys. Chem. 1993, 97, 531-533. [CrossRef]

53. Muñoz, J.; Domènech, $\mathrm{X}$. $\mathrm{TiO}_{2}$ catalysed reduction of $\mathrm{Cr}(\mathrm{VI})$ in aqueous solutions under ultraviolet illumination. J. Appl. Electrochem. 1990, 20, 518-521. [CrossRef]

54. Lu, H.; Fan, W.; Dong, H.; Liu, L. Dependence of the irradiation conditions and crystalline phases of $\mathrm{TiO}_{2}$ nanoparticles on their toxicity to Daphnia magna. Environ. Sci. Nano 2016, 4, 406-414. [CrossRef]

55. Sclafani, A.; Herrmann, J.M. Comparison of the photoelectronic and photocatalytic activities of various anatase and rutile forms of titania in pure liquid organic phases and in aqueous solutions. J. Phys. Chem. 1996, 100, 13655-13661. [CrossRef]

56. Botta, S.G.; Navío, J.A.; Hidalgo, M.C.; Restrepo, G.M.; Litter, M.I. Photocatalytic properties of $\mathrm{ZrO}_{2}$ and Fe/ $\mathrm{ZrO}_{2}$ semiconductors prepared by a sol-gel technique. J. Photochem. Photobiol. A Chem. 1999, 129, 89-99. [CrossRef]

57. Testa, J.J.; Grela, M.A.; Litter, M.I. Experimental evidence in favor of an initial one-electron-transfer process in the heterogeneous photocatalytic reduction of chromium(VI) over $\mathrm{TiO}_{2}$. Langmuir 2001, 17, 3515-3517. [CrossRef]

58. Sun, B.; Reddy, E.P.; Smirniotis, P.G. Visible light Cr(VI) reduction and organic chemical oxidation by Tio 2 photocatalysis. Environ. Sci. Technol. 2005, 39, 6251-6259. [CrossRef]

59. Chakrabarti, S.; Dutta, B.K. Photocatalytic degradation of model textile dyes in wastewater using $\mathrm{ZnO}$ as semiconductor catalyst. J. Hazard. Mater. 2004, 112, 269-278. [CrossRef]

60. Shaban, Y.A. Effective photocatalytic reduction of $\mathrm{Cr}(\mathrm{VI})$ by carbon modified (CM)-n- $\mathrm{TiO}_{2}$ nanoparticles under solar irradiation. World J. Nano Sci. Eng. 2013, 3, 154-160. [CrossRef]

61. Bashirom, N.; Tan, W.K.; Kawamura, G.; Matsuda, A.; Lockman, Z. Comparison of $\mathrm{ZrO}_{2}$, $\mathrm{TiO}_{2}$, and $\alpha-\mathrm{Fe}_{2} \mathrm{O}_{3}$ nanotube arrays on $\mathrm{Cr}(\mathrm{VI})$ photoreduction fabricated by anodization of $\mathrm{Zr}$, Ti, and Fe foils. Mater. Res. Express 2020, 7, 055013. [CrossRef]

62. Wang, S.Q.; Bi, B.; Zhao, X.J. Study on photocatalytic reduction of $\mathrm{Cr}(\mathrm{VI})$ by fluorine-doped $\mathrm{TiO}_{2}$. Key Eng. Mater. 2017, 727, 841-846. [CrossRef]

63. Liu, L.; Luo, C.; Xiong, J.; Yang, Z.; Zhang, Y.; Cai, Y.; Gu, H. Reduced graphene oxide (rGO) decorated TiO 2 microspheres for visible-light photocatalytic reduction of Cr(VI). J. Alloys Compd. 2017, 690, 771-776. [CrossRef]

64. Zhao, Y.; Zhao, D.; Chen, C.; Wang, X. Enhanced photo-reduction and removal of $\mathrm{Cr}(\mathrm{VI})$ on reduced graphene oxide decorated with $\mathrm{TiO}_{2}$ nanoparticles. J. Colloid Interface Sci. 2013, 405, 211-217. [CrossRef]

65. Lei, X.; Zhang, Z.; Wu, Z.; Piao, Y.; Chen, C.; Li, X.; Xue, X.; Yang, H. Synthesis and characterization of Fe, N and C tri-doped polymorphic $\mathrm{TiO}_{2}$ and the visible light photocatalytic reduction of $\mathrm{Cr}(\mathrm{VI})$. Sep. Purif. Technol. 2017, 174, 66-74. [CrossRef]

66. Rahmat, S.; Tan, W.K.; Kawamura, G.; Matsuda, A.; Lockman, Z. Facile fabrication of rGO/rutile $\mathrm{TiO}_{2}$ nanowires as photocatalyst for Cr(VI) reduction. Mater. Today Proc. 2019, 17, 1143-1151. [CrossRef]

67. Djellabi, R.; Ghorab, F.M.; Nouacer, S.; Smara, A.; Khireddine, O. Cr(VI) photocatalytic reduction under sunlight followed by $\mathrm{Cr}(\mathrm{III})$ extraction from $\mathrm{TiO}_{2}$ surface. Mater. Lett. 2016, 176, 106-109. [CrossRef] 